\title{
$\mathrm{PMO}$ 기반 프로젝트 관리 시스템의 설계 및 적용*
}

\author{
정천수 $* *$ · 김승렬*** · 김남규****
}

I. 서론

ㅍ. 관련연구

2.1 프로젝트 관리 시스템(PMS)

2.2 프로젝트 관리 조직(PMO)

III. PMO 기반의 프로젝트 관리 시스템 설계

3.1 PMO-based PMS(PbPMS) 개요

$3.2 \mathrm{PbPMS}$ 설계 프로세스및 산출물

3.2.1 요구사항 분석

3.2 .2 논리 데이터모델 설계

3.2 .3 화면 설계
<목 차>

IV. 사례 분석-"K"은행 차세대 시스템 구축

4.1 사례 개요

4.2 " $\mathrm{K}$ " 은행 통합품질관리시스템

4.3 " $\mathrm{K}$ " 은행의 통합품질관리시스템 활용 성과 평가

$\mathrm{V}$. 결론

참고문헌

$<$ Abstract $>$

\section{I. 서론}

1990년대 초반부터 많은 SI(System Integration) 업체들은 효율적인 프로젝트 관리를 통해 품질 높은 소프트웨어를 적기에 제공하기 위한 방안을 모색해왔다(조재성과 박주철, 2008). 같은 시기 에 학계에서는 개발방법론, 자동화 도구, 품질 관리 측면에서 정보시스템 개발 프로젝트의 성공 률을 높이기 위한 다양한 연구(Orlikowski, 1989; Rai and Howard, 1993;Rai and Patnayakuni,
1996; Ruso, 1993)가 수행되어 왔다. 이러한 연구 의 성과로 프로젝트 생성에서부터 종료에 이르는 전 과정을 관리하는 프로젝트관리시스템(Project Management Systems: PMS)이 현업에 널리 보 급되어 사용되고 있으며, 최근의 $\mathrm{PMS}$ 는 초창기 의 프로젝트 관리를 위한 보조 수단에서 벗어나 프로젝트의 성공적 수행을 위한 필수 도구로 인식 되고 있다. 최근 정보화 프로젝트의 규모가 성장 하고 분야가 다양해짐에 따라 효율적인 프로젝트 관리의 필요성이 더욱 강조되고 있으며, 이러한

* 본 연구는 2011년도 국민대학교 교내연구비 지원으로 수행됨

** 국민대학교 비즈니스IT전문대학원 박사과정, paripal@kookmin.ac.kr

*** 국민대학교 경영정보학부 교수, 교신저자, srkim@kookmin.ac.kr

**** 국민대학교 경영정보학부 조교수, ngkim@kookmin.ac.kr 
필요는 미국의 프로젝트 관리협회(Project Management Institute: PMI)에서 발표한 프로젝 트 관리를 위한 핵심지식체계인 PMBOK(Project Management Body of Knowledge)(PMI, 2004) 를 중심으로 하여 프로젝트 관리도구의 개발 및 구축에 대한 꾸준한 투자로 이어지고 있다(옹상 순외, 2009).

$\mathrm{PMS}$ 를 비롯한 기존의 다양한 프로젝트 관리 지원 도구들이 소규모의 정형화된 프로젝트의 관리에 있어서 효용성을 입증해 온 것이 사실이 지만, 이들 도구들은 최근의 대형화, 복잡화된 프로젝트를 효과적으로 지원하기에는 많은 한계 를 갖는 것으로 알려져 있다. 대형 프로젝트 관리 의 어려움은 크게 다음의 세 가지 측면에서 파악 될 수 있다. 우선 대형 프로젝트의 경우 서로 다 른 관점을 갖는 다양한 이해 당사자가 존재하기 때문에 이해관계의 상충이 비일비재하게 발생한 다. 특히 고객의 요구사항은 곧 개발 비용으로 직결되기 때문에 프로젝트 수행 업체와 고객 간 에는 크고 작은 대립 구조가 형성되는 것이 일반
적이다. 또한 고객과 수행 업체 간의 정보의 비대 칭성은 대형 프로젝트에서 더욱 크게 발생한다. 즉 개발의 진행상황 및 이슈가 고객에게 적기에 전달되기 어려울 뿐 아니라, 대규모 프로젝트를 수행한 경험이 없는 고객의 경우 전문지식 및 경 험 부족으로 인해 신속하고 합당한 의사결정을 내리기 어려운 경우가 많다. 마지막으로 대규모 의 장기 프로젝트일수록 더욱 다양한 위험요소 가 존재(홍사능, 2010)한다는 점도 관리의 어려 움으로 작용한다. 즉, 이슈, 업무, 일정, 범위, 자 원 등의 모든 측면에서 예측하지 못한 변수가 발 생할 수 있으며(정철용과 손동기, 2006), 이는 곧 예산 초과, 납기 지연, 품질 저하 등의 현상을 초래할 수 있다.

위와 같은 대형 프로젝트 관리의 어려움을 극 복하기 위해 최근 많은 기업들이 $\mathrm{PMO}$ (Project Management Office)를 도입하고 있다. PMO란 기업내에서 진행 중인 모든 프로젝트 통합 및 프 로젝트 포트폴리오를 관리하는 조직(PMI, 2004) 을 의미하며, 고객을 대신하여 대형 프로젝트를

<표 1> $\mathrm{PMO}$ 의 5가지 핵심 기능

\begin{tabular}{|c|c|}
\hline 핵심 기능 & 수행 내용 \\
\hline 일정 관리 & $\begin{array}{l}\text { - 프로젝트 전체 일정 관리 및 범위의 명확한 설정 } \\
\text { - 프로젝트 관련 벤더와의 계약 관리 }\end{array}$ \\
\hline 의사소통 관리 & $\begin{array}{l}\text { - 주요 이해관계자들에 대한 원활한 의사소통 지원 및 중재 } \\
\text { - 주요 이해관계자들에 대한 명확한 R\&R 설정 }\end{array}$ \\
\hline 위험 관리 & $\begin{array}{l}\text { - 발생 가능한 위험의 예측 및 이에 대한 대응방안 수립 } \\
\text { - 체계적인 위험관리 및 이에 대한 보고방안 수립 }\end{array}$ \\
\hline 자원 관리 & $\begin{array}{l}\text { - 프로젝트에 소요되는 자원의 정의 및 예측 } \\
\text { - 프로젝트 소요 자원의 투명하고 효율적인 관리 }\end{array}$ \\
\hline 품질 관리 & $\begin{array}{l}\text { - 산출물에 대한 품질보증 및 고객 요구 부합도 분석 및 평가 } \\
\text { - 세부 조직별 성과지표 설정 및 지속적인 성과 관리 }\end{array}$ \\
\hline
\end{tabular}


진행, 관리, 평가하는 역할을 담당한다. 예를 들 어 고객과 프로젝트 수행 업체 간에 역할과 책임 (Roles \& Responsibility: R\&R)에 대한 이견이 발생할 때, $\mathrm{PMO}$ 는 이에 대한 현실적 중재안을 제시하고 합의를 도출하는 주체가 된다. 즉 $\mathrm{PMO}$ 는 프로젝트 전 분야의 총괄 관리를 통해 프로젝 트의 성공적인 추진을 지원하는 조직으로서, 구 체적으로는 <표 1>의 5 가지 핵심 기능을 수행한 다.

Standish Group의 2006년 조사(The Standish Group International Inc., 2006)에 의하면, 프로 젝트의 규모가 대형화되고 동시 진행되는 프로 젝트의 수가 점차 증가함에 따라, 정보시스템 개 발 프로젝트 성공률은 1 2년 전에 비하여 34\% 에서 $28 \%$ 정도로 하락하였으며, 착수 단계에서 취소된 프로젝트의 비율도 $15 ~ 18 \%$ 에 달하는 것 으로 파악되었다. 또한 이 연구에 따르면 완료된 프로젝트의 반 이상이 최초 예상 비용의 $189 \%$ 이상을 지출하였으며, 1 년 이상의 장기 프로젝트 중에서 최초 계획된 일정의 두 배 이상의 기간이 소요된 프로젝트도 $35 \%$ 이상인 것으로 나타났 다. 또한 일정 지연, 예산 초과, 성과 달성 실패 등의 중대한 위험요인을 갖고 있는 IS 관련 프로 젝트의 비율은 무려 $51 \%$ 에 달하는 것으로 나타 났다. 이와 대조적으로 최근 $\mathrm{PMO}$ 를 도입한 기 업의 프로젝트 성공률은 현격히 향상된 것으로 나타났다. 구체적으로 정보시스템 개발 프로젝 트의 성공률은 PMO 도입 1년 내에 $37 \%$ 로, 2년 내에는 $62 \%$ 로 향상될 수 있는 것으로 알려져 있다(BIA, 2005).

이처럼 $\mathrm{PMO}$ 도입의 효과 및 당위성은 이미 많은 분석 결과들을 통해 충분히 뒷받침되어 왔 으며, 현재는 어떤 특징을 갖는 프로젝트가 어떤
방식을 통해 PMO 기반으로 수행되었을 때 $\mathrm{PMO}$ 도입의 효과가 극대화되는지에 대한 연구 가 필요한 시기라고 할 수 있다. 현재까지의 경험 적 분석에 의하면 $\mathrm{PMO}$ 도입의 효과는 100 억 이상 규모의 대형 프로젝트, 그리고 1년 6개월 이상의 장기 프로젝트에서 더욱 확실히 나타나 는 것으로 알려져 있다. 이러한 프로젝트는 주로 다양한 시스템의 통합 또는 전체 시스템의 신규 개발의 성격을 갖는 경우가 많으며, 대표적으로 금융권의 차세대 시스템 구축 프로젝트가 이러 한 유형에 해당된다. 실제로 국내에서는 2002년 금융권의 차세대 프로젝트 붐이 형성되면서, 제 1 금융권의 많은 기업들이 $\mathrm{PMO}$ 조직을 통해 대형 프로젝트를 성공적으로 추진한 사례가 다수 발 견된다.

이와 같은 $\mathrm{PMO}$ 의 유용성에도 불구하고, $\mathrm{PMO}$ 의 도입이 곧바로 프로젝트의 성공적 수행 으로 직결되는 것은 아니다. $\mathrm{PMO}$ 기반 프로젝 트 수행 시 가장 문제가 되는 부분은, 새로운 체 계인 $\mathrm{PMO}$ 환경에서 프로젝트의 수행을 효과적 으로 지원할 수 있는 적합한 PMS 가 존재하지 않는다는 점이다. 즉 기존의 $\mathrm{PMS}$ 에는 $\mathrm{PMO}$ 에 대한 개념이 충실하게 반영되어 있지 않기 때문 에, 단순 업무는 PMS에 의해서 수행되고 정작 $\mathrm{PMO}$ 의 중요한 기능은 시스템의 충분한 지원 없 이 수동적으로 수행되고 있는 현실이다. 실제로 $\mathrm{PMO}$ 기반의 프로젝트를 추진한 기업들의 경우, $\mathrm{PMS}$ 를 통해 제한적 수준의 프로젝트 관리 및 정보 공유가 이루어졌으며, 필요한 산출물을 출 력하여 PMO 보고 및 회의에 사용한 것으로 보 고되고 있다.. 즉 프로젝트의 원활한 수행을 위해 고안된 기존의 $\mathrm{PMS}$ 가 새로운 체제인 $\mathrm{PMO}$ 기 반의 프로젝트 수행 과정에서는 오히려 방해 요 
인으로 작용하고 있는 것이다.

프로젝트의 대부분 단계에서 $\mathrm{PMO}$ 의 기능이 부족한 $\mathrm{PMS}$ 는 비효율을 야기하게 되며, 프로젝 트의 시작 단계인 착수 단계에서도 이러한 현상 이 나타나게 된다. <그림 1>은 PM, 주관팀장, 시스템계정담당, 그리고 $\mathrm{PMO}$ 가 관여된 프로젝 트 착수 단계의 계획관리 프로세스를 보여준다. 프로세스 중 굵은 선으로 나타난 부분, 즉 $\mathrm{PMO}$ 의 검토 및 승인이 필요한 부분은 $\mathrm{PMO}$ 와 다른 참여자 간의 정보 흐름이 발생하는 프로세스를 나타낸다. $\mathrm{PMO}$ 의 역할과 권한이 반영되지 않은 $\mathrm{PMS}$ 의 경우 이러한 정보 흐름 발생 시 앞에서 언급한 바와 같이 정보의 전달과 승인 과정이 시 스템 내에서 이루어지지 않고 출력물을 통해 오 프라인으로 이루어지며, 이는 전체 효율성의 저
하로 이어지게 된다. 따라서 $\mathrm{PMO}$ 의 역할과 권 한을 $\mathrm{PMS}$ 에 포함시킴으로써 이와 같은 프로세 스의 과정도 PMS 내에서 수행될 수 있으며, 이 를 통해 전체 프로젝트 수행의 효율성을 높일 수 있을 것이다.

본 논문의 이후 구성은 다음과 같다. 다음 장 인 2장에서는 $\mathrm{PMS}$ 와 $\mathrm{PMO}$ 에 대한 기존의 연구 결과들을 간략하게 소개하고, 3 장에서는 $\mathrm{PMO}$ 관점의 $\mathrm{PMS}$ 설계 및 구축 방안을 구체적 기능 및 설계 산출물 위주로 제시한다. 개발된 시스템 을 실제 현업의 정보시스템 개발 프로젝트에 적 용한 사례는 4장에서 소개하며, 마지막 장인 5 장에서는 본 연구의 기여 및 한계, 그리고 향후 연구 방향을 제시한다.

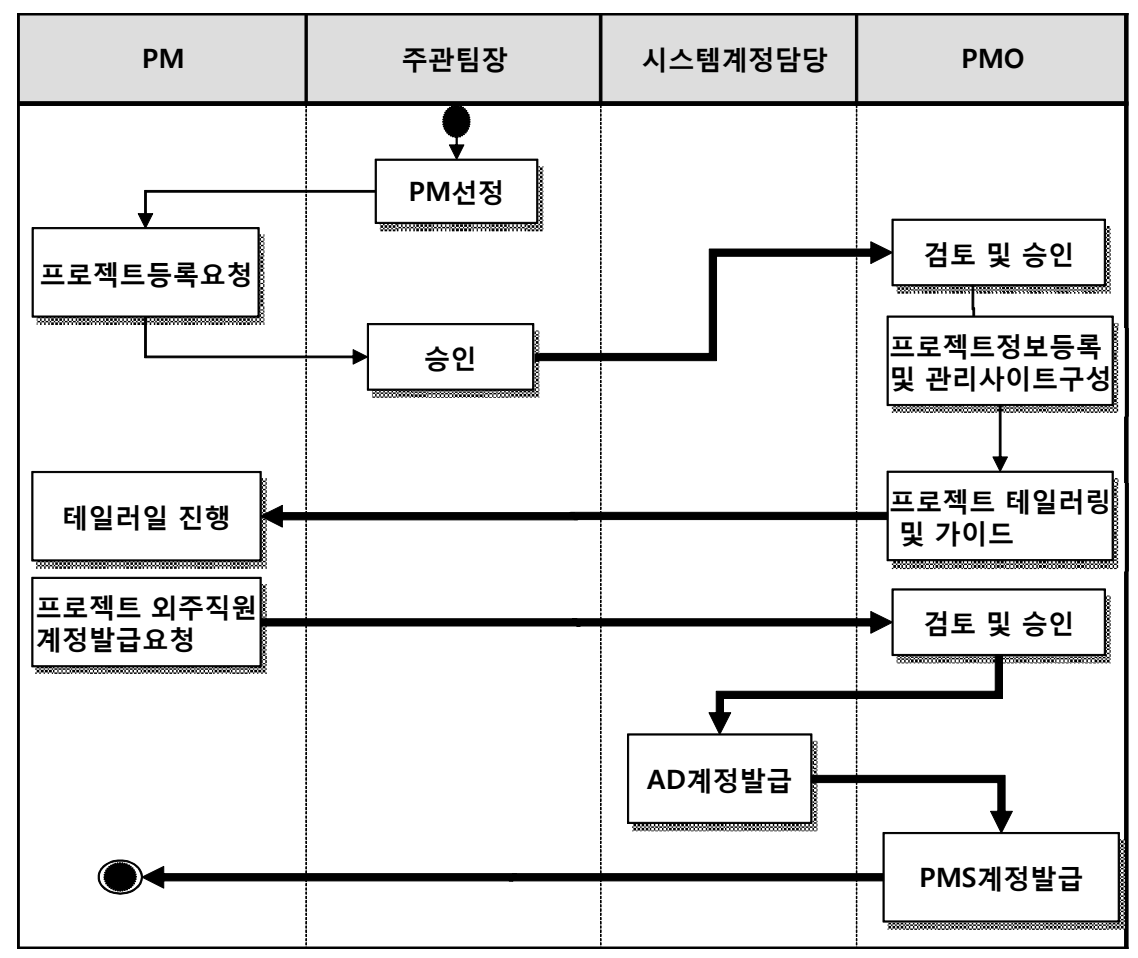

<그림 1> $\mathrm{PMO}$ 와 다른 참여자 간의 정보 교류 예 - 계획 관리 


\section{II. 관련 연구}

\section{1 프로젝트 관리 시스템(PMS)}

프로젝트 관리란 프로젝트와 관련된 이해당 사자를 만족시키기 위하여 스킬, 기법, 지식을 프로젝트 활동에 적용하는 것을 의미하며, 일정 및 범위 관리, 품질 관리, 이슈 및 위험 관리, 인 력자원 관리, 의사소통 관리, 비용 관리, 조달 관 리 등을 대상으로 한다(김상열외, 2004; 김상열 과 장윤희, 2006). PMS는 프로젝트 관리가 효율 적이고 체계적으로 이루어지게끔 지원하는 도구 로, 모니터링 강화, 사용자 범위 확대, 관리 효율 성 증대, 경험/지식/자료 등의 원활한 공유 등을 주요 목표로 한다. 즉 PMS는 프로젝트를 관리하 는데 사용되는 도구, 기법, 방법론, 자원, 절차들 의 집합체를 의미하며, 프로젝트 관리자가 프로 젝트를 성공적으로 추진하기 위한 중요한 도구 (PMI, 2004)가 된다. 프로젝트의 계획, 공고, 신
청, 평가, 선정, 과제종료 등 프로젝트의 전 수명 주기에 걸쳐 일정관리, 각종 평가, 예산의 통제, 관련 통계의 산출 및 분석 등의 업무(김석훈외, 2009)가 PMS에 의해 수행된다.

$\mathrm{ERP}$, 구매관리시스템, 생산관리 시스템 등의 일반 전산시스템이 정형화된 업무를 반복적으로 처리하는 것에 비해, PMS는 일회성으로 발생하 는 비정형, 반 정형적인 업무인 프로젝트를 관리 하는 것을 목적으로 하는 시스템이다. 즉 PMS는 $\mathrm{SI}$ 프로젝트, 건설프로젝트, R\&D 프로젝트, 마 케팅 및 특별 태스크 등 다양한 유형의 프로젝트 관리에 사용되며, 관리하고자 하는 프로젝트의 업무 성격에 따라 매우 다른 특성을 갖게 된다 (김희영, 2008). <표 2>는 국내 한 업체에서 PMS의 도입을 위해 내부적으로 국내, 국외에서 널리 사용되고 있는 다양한 상용 PMS 제품을 간략하게 비교한 결과를 보여준다.

<표 2> 상용 PMS 제품 비교

\begin{tabular}{|c|c|c|c|}
\hline 구분 & 개발사(제품명) & 수준 & 비고 \\
\hline $\begin{array}{c}\text { 국내제 } \\
\text { 품 }\end{array}$ & $\begin{array}{l}\text { 미로직스(PMeX) } \\
\text { 리얼웹(RealPMS) } \\
\text { 유비티즌(iPERT) } \\
\text { JSC\&I(Planmate) } \\
\text { PMwiz(MSP) } \\
\text { 세윤CNS(Wiser) } \\
\text { 유토닉스(UTO*PMS) }\end{array}$ & $\begin{array}{l}5 \\
5 \\
4 \\
1 \\
6 \\
7 \\
2\end{array}$ & $\begin{array}{l}\text { 영업, 구매, 공정관리 위주 } \\
\mathrm{BPM} \text { 기반, 유연성이 떨어짐 } \\
\mathrm{C} / \mathrm{S}, \mathrm{CPM} \text { (일정관리) } \\
\mathrm{C} / \mathrm{S}, \text { 일정관리(건설) } \\
\text { 요구사항 반영이 어려움 } \\
\text { 품질관리 등 일부 기능 부재 } \\
\text { 통합관리가 어려움 }\end{array}$ \\
\hline $\begin{array}{c}\text { 외산제 } \\
\text { 품 }\end{array}$ & $\begin{array}{l}\text { 한국PM소프트(Artemis) } \\
\text { Oracle(Primavera) } \\
\text { MicroSoft(MSP, EPM) } \\
\text { Compuware(Changepoint) } \\
\text { HP(PPMC) } \\
\text { CA(Clarity) }\end{array}$ & $\begin{array}{l}8 \\
8 \\
5 \\
8 \\
8 \\
8\end{array}$ & $\begin{array}{l}\text { UI 복잡, 요구사항 반영문제 } \\
\text { UI 복잡, 요구사항 반영문제 } \\
\text { 대중화, 세부관리 어려움 } \\
\text { 공정관리 미흡 } \\
\text { UI 복잡, Dashboard빈약 } \\
\text { UI 복잡, Dashboard빈약 }\end{array}$ \\
\hline
\end{tabular}


' 정보시스템연구」 제20권 제4호, 2011년 12월

* 범례(상대비교): 1 4[일정관리중심], 5 7[일 정+협업중심], 8 10[PMBOK+CMMI]

<표 2>의 각 제품은 서로 다른 장단점을 갖고 있지만, 전체적으로 다음과 같은 몇 가지 측면에 서 개선될 필요가 있다. 현재까지의 PMS제품들 은 전반적으로 사용법이 어려워서 별도의 교육 이 필요하며, 관리자와 팀원 간의 의사소통 기능 이 미흡하다. 이러한 특징은 대표적 상용 PMS 중 하나인 MS-Project에서도 동일하게 나타난다 (조재성과 박주철, 2008). 또한 대부분의 PMS가 프로젝트의 일회성 관리에 주안점을 두었기 때 문에, 피드백을 통한 통합적, 지속적 프로젝트 관리에는 적합하지 않다는 한계를 갖는다. 무엇 보다도 기존의 $\mathrm{PMS}$ 에는 $\mathrm{PMO}$ 에 대한 개념이 충실하게 반영되어 있지 않기 때문에 정작 $\mathrm{PMO}$ 의 중요한 기능은 시스템의 지원이 거의 불가능 하다. 이러한 이유로 $\mathrm{PMO}$ 기반의 대형 프로젝 트를 기획하고 있는 기업들을 중심으로, $\mathrm{PMO}$ 의 역할과 권한이 충실히 반영된 $\mathrm{PMS}$ 에 대한 요구 가 증가하고 있다.

\section{2 프로젝트 관리 조직(PMO)}

과거 정보시스템 부서의 업무는 운영업무가 $80 \%$ 이상을 차지하고 있었으며, 프로젝트는 매 우 드물게 발생하는 일회성 사건이었다. 그러나 현재는 여러 프로젝트가 동시에 진행되는 것이 일반적일 만큼 프로젝트의 수가 증가하였으며, 이로 인해 프로젝트 효율적 관리능력이 매우 중 요하게 인식되고 있다. 즉, 최근 기업 경영에서 정보시스템이 차지하는 비중이 확대되고 수천억 원 규모의 복잡한 IT프로젝트가 빈번히 수행됨
에 따라, 이를 효율적이고 성공적으로 수행하기 위한 전담 관리 조직이 필요하다는 인식(김상열 외, 2004; 김상열과 장윤희, 2006) 에서PMO의 도입이 확산되었다.

$\mathrm{PMO}$ 는 기업 내에서 진행 중인 모든 프로젝트 를 통합 관리하고, 이를 위해 프로젝트 방법론, 프로세스 및 절차, 통제, 도구, 인력, 교육훈련 등의 기능을 수행한다. 따라서 $\mathrm{PMO}$ 를 운영한다 는 것은 해당 회사의 프로젝트 관리 방법을 공식 화 한다는 것(Chase and Stewart, 1994)으로 해 석되기도 한다. 한편, $\mathrm{PMO}$ 서비스를 제공하고 있는 컨설팅 및 $\mathrm{SI}$ 업체들은 $\mathrm{PMO}$ 를 단위 프로 젝트가 모여 10 개월이 넘는 대형 프로그램을 이 루는 경우에 대한 전문적인 관리 서비스 혹은 조 직으로 정의하고 있다. $\mathrm{PMO}$ 는 보통 1 2년 단위 로 단위 프로젝트 간 이해관계 조정 및 통합 관리 를 수행하고, 구체적으로는 공통 표준 및 가이드 제시, 실행여부 점검, 일정/범위/이슈 통합 관리, 구축 이후 운영계획수립, 통합 테스트 및 이행준 비 등을 담당한다. 반면, 2 3년의 중장기 관점에 서 전사의 프로젝트 포트폴리오를 관리하는 서 비스 혹은 조직은 EPMO(Enterprise Program Management Office)라고 하며, 프로그램/프로 젝트 포트폴리오 관리, 추진 타당성 평가 및 수행 후 성과평가, 예산의 관리 및 통제 등을 담당한 다. 이처럼 $\mathrm{PMO}$ 에 대한 여러 정의를 종합하면, $\mathrm{PMO}$ 란 품질 관리에서부터 위험 관리 및 일정 관리, 산출물 관리 등에 이르기까지 프로젝트 전 분야를 총괄 관리하는 기관으로서, 체계적인 프 로젝트 관리체제 구축과 프로젝트 수행 중 발생 가능한 위험 요소들에 대한 효과적인 관리 및 통 제, 품질 관리를 통해 프로젝트의 성공적인 추진 을 지원하는 조직이라 할 수 있다. 
국내에서는 2002년이후 은행권을 중심으로 차세대 프로젝트 붐이 일면서 프로젝트의 성과 향상을 위해 자체적 혹은 외부적으로 $\mathrm{PMO}$ 가 도 입되었다. 국내 기업의 초기 $\mathrm{PMO}$ 는 대부분 외 부 전문 기관에 위탁운영되어 왔으며, 2011년 제 1 금융권의 차세대 프로젝트가 마무리되면서 $\mathrm{PMO}$ 에 대한 인식이 높아짐에 따라 대규모 프로 젝트에서는 $\mathrm{PMO}$ 조직이 필수로 구성되는 것이 일반화되었다.

$\mathrm{PMO}$ 가 갖추어야 할 필수 기능에 대해 많은 연구(Chase and Stewart, 1994; Dai and Wells, 2004; Hill, 2004; Orwig and Brennan, 2000; Parasuraman et al., 1991; Rad and Levin, 2002) 에서 활발한 논의가 이루어졌다. Chase and Stewart(1994)는 프로젝트 보고, 프로젝트 템플 릿 개발, 프로젝트 산출물 유지 보수 등의 업무를 수행하고 개발자와 현업간의 중간자적 위치를 확보하여 사용자로부터의 요구사항 수렴과 검토 의견을 정리하여 개발자에게 넘기는 기능을 $\mathrm{PMO}$ 의 핵심 기능으로 파악하였다. 또한 $\mathrm{PMO}$ 는 프로젝트 산출물 및 산출물 관련자 검토를 위 한 중간자로서의 역할을 수행해야 하며(Chase and Stewart, 1994), 프로젝트의 원활한 진행을
위한 리더쉽을 제공해야 한다(Orwig and Brennan, 2000). 한편 Dai and Wells(2004)는 $\mathrm{PMO}$ 의 기능을 6 가지로 정의하고 각각의 기능 들이 프로젝트 수행 시, 실제로 얼마나 사용되었 는지에 대한 연구를 수행하였으며, 그 결과는 <표 3>에 나타나있다. 김상열과 장윤희(2006)의 연구에서는 이와 같은 다양한 선행 연구들을 포 함하여 $\mathrm{PMO}$ 의 핵심 기능에 대한 비교가 이루어 졌으며, <표 4>는 그 내용의 일부를 다시 정리하 여 소개하고 있다.

<표 3> $\mathrm{PMO}$ 의 기능의 활용률(Day and Wells, 2004)

\begin{tabular}{|l|c|}
\hline \multicolumn{1}{|c|}{$\mathrm{PMO}$ 기능 } & 활용률(\%) \\
\hline 프로젝트 관리 표준 및 방법론 & 100 \\
\hline 프로젝트 이력 보관 & 64.5 \\
\hline 일반관리 지원 & 70.8 \\
\hline 인력관리 & 28.13 \\
\hline PM교육 & 70.83 \\
\hline 프로젝트 자문 및 멘토 & 79.17 \\
\hline
\end{tabular}

이와 같이 $\mathrm{PMO}$ 의 주요 기능은 프로젝트 이해관 계자간의 중간자로서 프로젝트의 전체 부분에 걸쳐 수행된다. 따라서 $\mathrm{PMO}$ 는 프로젝트 착수

<표 4> PMO의 핵심 기능에 대한 선행 연구(김상열과 장윤희, 2006)

\begin{tabular}{|l|l|}
\hline \multicolumn{1}{|c|}{ 연구자 } & \multicolumn{1}{c|}{ PMO 기능 } \\
\hline Parasuraman et al.(1991) & 품질관리 \\
\hline Chase and Stewart(1994) & 중간자적 역할 \\
\hline Orwig and Brennan(2000) & 구조적 지원과 리더쉽 \\
\hline Rad and Levin(2002) & 증진, 축적, 실행, 훈련, 자문, 멘토, 증대 \\
\hline Hill(2004) & 실행관리, 기반관리, 자원통합관리, 기술지원, 업무와의 연계성 \\
\hline Dai and Wells(2004) & $\begin{array}{l}\text { 프로젝트 관리 표준, 방법론, 과거 데이터, 일반 관리 지원, 인력관리, } \\
\text { 프로젝트 자문 및 멘토, 교육 }\end{array}$ \\
\hline
\end{tabular}


이전부터 고객과의 협의를 통해 프로젝트관리 방안을 수립해야 하며, 기존의 $\mathrm{PMS}$ 를 활용하여 프로젝트 관리를 효과적으로 수행할 수 있는 접 점을 모색하게 된다. 하지만 대부분의 기존 PMS 제품들은 각 업체별로 내세우는 특화된 기능에 집중하여 구현되었기 때문에 프로젝트 관리의 모든 기능을 충실히 지원하기가 매우 어렵다. 또 한 기능의 구성 자체가 다소 경직되어있기 때문 에, $\mathrm{PMO}$ 의 다양한 기능을 유연하게 수용하기 어렵다는 한계를 갖는다. 따라서 $\mathrm{PMO}$ 기반의 프로젝트가 원활하게 수행되기 위해서는 $\mathrm{PMO}$ 의 다양한 기능을 충실히 포함하는 완성도 높은 $\mathrm{PMS}$ 의 개발이 반드시 필요하다고 할 수 있다.
III. PMO 기반의 프로젝트 관리 시스템 설계

본 장에서는 본 연구에서 제안하는 $\mathrm{PMO}$ 기반 의 프로젝트관리시스템(PMO-based PMS $\mathrm{PbPMS})$ 의 전체 구조 및 설계 과정에 대해 설명 한다. 첫 절인 3.1절에서는 $\mathrm{PbPMS}$ 가 갖춰야 할 필요 기능들을 먼저 파악하고, 이러한 기능들을 지원하는 $\mathrm{PbPMS}$ 의 전체 시스템 구성에 대해 간 략히 살펴본다. 전체 시스템의 설계 과정은 크게 요구사항분석, 논리 데이터모델 설계, 화면 설계 의 단계로 구성되며, 이들 단계에 대한 상세 설명 과 과정별 산출물에 대한 설명은 3.2절에서 다루

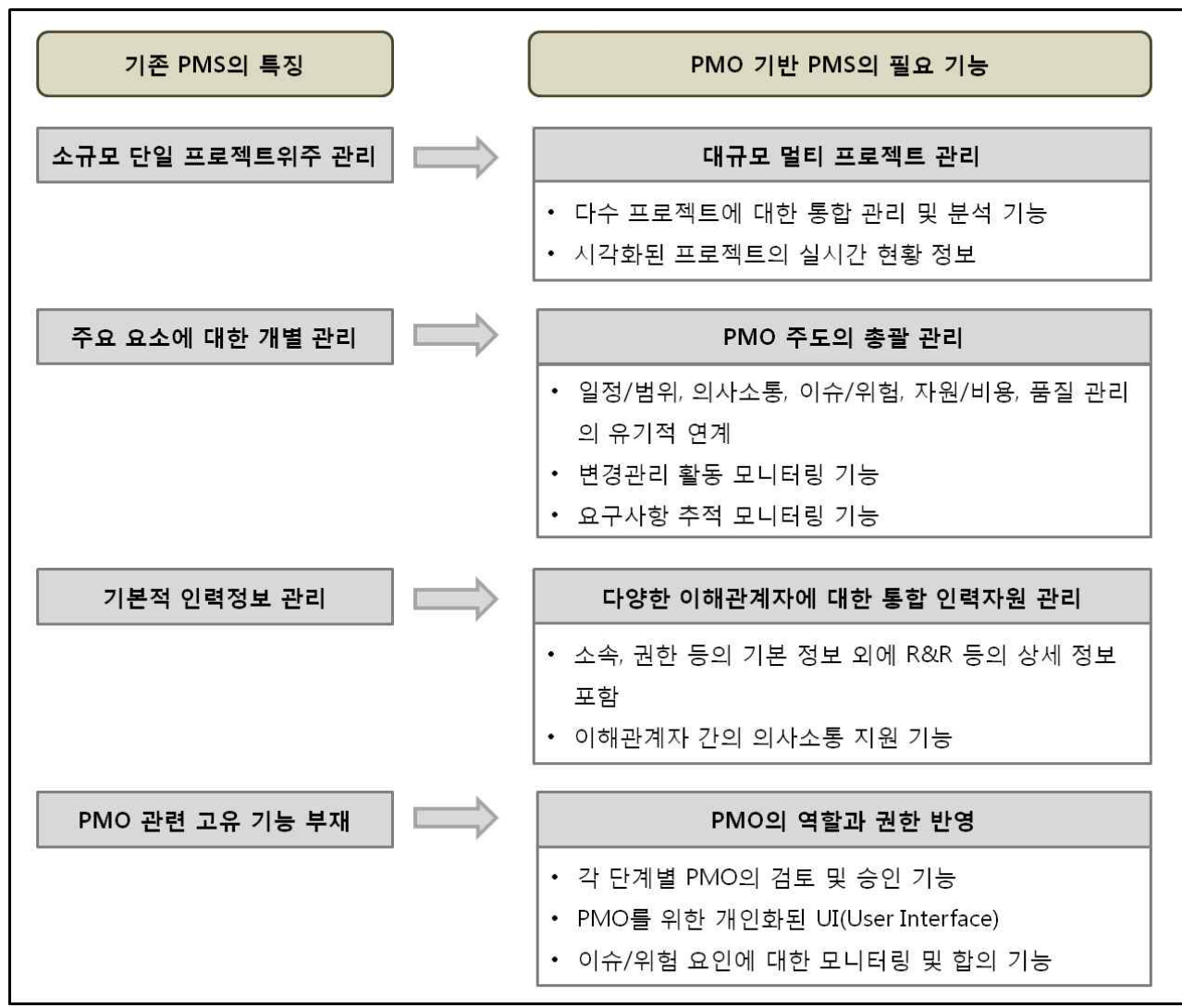

<그림 2> 기존 $\mathrm{PMS}$ 의 특징 및 $\mathrm{PMO}$ 기반 $\mathrm{PMS}$ 의 필요 기능 
기로 한다.

\subsection{PMO-based PMS(PbPMS) 개요}

$\mathrm{PMS}$ 는 하나의 특정 프로젝트의 관리를 목적 으로 개발된 제품이 대부분이므로, 서로 다른 특 성을 갖는 여러 프로젝트를 동시에 관리해야 하 는 PMO 체제에서 사용되기에는 어려움이 있다. <그림 2>는 기존의 PMS의 특징, 그리고 이러한 $\mathrm{PMS}$ 가 $\mathrm{PMO}$ 기반 프로젝트에서 활용되기 위해 추가로 필요한 실무 관점에서의 필수 필요 기능 을 보여준다. 이처럼 현재 PMS가 제공하는 기능 과 실제 현업에서 $\mathrm{PMO}$ 기반의 프로젝트 수행 시 필요로 하는 기능 사이에 차이가 존재하기 때 문에, $\mathrm{PMO}$ 기반의 대형 프로젝트를 기획하고 있는 기업들을 중심으로 $\mathrm{PMO}$ 의 역할과 권한이 충실히 반영된 $\mathrm{PMS}$ 에 대한 요구가 증가하고 있 다. 본 연구의 목적은 $\mathrm{PMO}$ 기반의 프로젝트를 효과적으로 수행하기 위한 기존 PMS의 개선 방 안을 도출하고, 필수 필요 기능을 파악하여 이를 실제 시스템으로 구현하는 것이다. 즉 $\mathrm{PMO}$ 의 역할과 권한이 충실히 반영된 $\mathrm{PMS}$ 의 구축을 통 해 실제 현업의 프로젝트 관리를 효과적으로 지 원하는 것이 본 연구의 목적이다.

앞에서 논의한 바에 의하면, $\mathrm{PMO}$ 기반의 프 로젝트 수행을 효과적으로 지원하기 위해 새로 고안되는 PMS가 반드시 갖춰야 하는 기능은 다 음과 같다. 우선 $\mathrm{PMO}$ 의 역할과 권한의 이행이 가능하도록 $\mathrm{PMO}$ 만의 개인화된 UI가 갖춰져야 한다. 또한 여러 프로젝트를 담당 $\mathrm{PMO}$ 별로 관 리할 수 있는 멀티 프로젝트 관리 기능이 반드시 구현되어야 한다. 또한 프로젝트 현황의 실시간 파악을 위한 시각적 Dashboard 기능 및 유연한
일정관리 기능, 그리고 요구사항의 도출부터 사 용자의 인계까지 추적할 수 있는 모니터링 기능 및 회의록과 연계된 실행항목관리를 통해 $\mathrm{PMO}$ 가 진행상태를 모니터링 할 수 있는 기능이 있어 야 한다. 그 외에도 다양한 이해관계자를 효과적 으로 관리하기 위한 확장된 인력자원 관리 기능 (소속, 등급, $\mathrm{R} \& \mathrm{R}$ 등의 정보 포함)이 제공되어 야 한다. $\mathrm{PMO}$ 의 역할이PMS를 통해 실질적으 로 구현되기 위해서는, $\mathrm{PMO}$ 가 관리 프로세스에 참여하여 승인 또는 합의할 수 있는 직접 모니터 링 기능이 포함되어야 한다. 따라서 프로젝트 각 단계별 확인, 상시 품질관리, 범위변경 관리, 변 경관리활동 모니터링, 이슈 및 리스크 모니터링 활동 등에 대해서는 $\mathrm{PMO}$ 가 직접승인프로세스 에 참여할 수 있어야 한다. 언급한 기능들은 <표 $5>$ 에 정리되어 있으며, 제안하는 시스템인 $\mathrm{PbPMS}$ 는 언급한 모든 기능을 지원할 수 있도록 설계되어야 한다. 또한 <표 5>는 제안하는 시스 템의 핵심 기능과 기존의 PMO 관련 연구에서 강조되어 온 $\mathrm{PMO}$ 의 필수 기능간의 대응관계를 보이고 있다.

제안하는 시스템인 PbPMS의 전체 구성도는 <그림 3>과 같다. 최하단의 PMS Repository에 는 프로젝트와 관련된 각종 정보들이 저장되어 있으며, Project Management Server Interface는 PMS Repository와 연동하여 사용자가 컴퓨터, 스마트폰 등의 유무선기기를 통해 서버에 저장 된 정보를 열람하거나 기록할 수 있도록 지원한 다. 최상단에는PbPMS의 사용자 유형이 나타나 있으며, $\mathrm{PMO}$ 가 별도의 유형으로 명확히 구분되 어 있음을 확인할 수 있다. 중간 부분은 $\mathrm{PbPMS}$ 의 핵심 기능으로 서버 및 사용자와 상호작용을 하게 되며, Initiation \& Plan Management, 
'정보시스템연구」제 20 권 제4호, 2011년 12월

<표 5>제안 시스템(PbPMS)의 목표 기능 요약

\begin{tabular}{|c|c|c|c|}
\hline $\begin{array}{l}\mathrm{PbPMS} \text { 의 } \\
\text { 목표기능 }\end{array}$ & 목표기능 상세 설명 & $\begin{array}{l}\text { 기능 범주 } \\
(<\text { 표4>) }\end{array}$ & $\begin{array}{c}\text { 주요 연구 } \\
(<\text { 표4>) }\end{array}$ \\
\hline $\begin{array}{c}\text { 멀티프로젝트관 } \\
\text { 리 }\end{array}$ & 유연한 멀티 프로젝트 관리 기능 & 자원통합관리 & Hill(2004) \\
\hline Dashboard 기능 & $\begin{array}{l}\text { - 프로젝트의 실시간 현황 파악을 위한 시각적 } \\
\text { Dashboard 기능 } \\
\text { - PMO만의 개인화된 UI }\end{array}$ & 자원통합관리 & Hill(2004) \\
\hline 인력자원관리 & $\begin{array}{l}\text { 소속별, 등급별, 투입계획, R\&R등에 따른상세 } \\
\text { 인력자원 관리 기능 }\end{array}$ & 인력관리 & $\begin{array}{c}\text { Dai and } \\
\text { Wells(2004) }\end{array}$ \\
\hline 요구사항관리 & 요구사항 추적관리 기능 & 실행관리 & Hill(2004) \\
\hline 의사소통관리 & 회의록과 연계된 실행항목관리 기능 & 실행관리 & Hill(2004) \\
\hline 품질관리 & 시스템을 통한 품질관리기능 & 품질관리 & $\begin{array}{l}\text { Parasuraman et } \\
\text { al.(1991) }\end{array}$ \\
\hline 이슈/리스크관리 & $\begin{array}{l}\mathrm{PMO} \text { 가 이슈/리스크를 실시간 모니터링 및 합 } \\
\text { 의할 수 있는 기능 }\end{array}$ & $\begin{array}{l}\text { 자문, 멘토, } \\
\text { 실행관리 }\end{array}$ & $\begin{array}{c}\text { Rad and } \\
\text { Levin(2002) }\end{array}$ \\
\hline 일정관리 & WBS 일정등록 및 변경관리 기능 & 실행관리 & Hill(2004) \\
\hline 범위변경관리 & $\begin{array}{l}\mathrm{PMO} \text { 가 범위변경에 대해 승인 및 합의 할 수 } \\
\text { 있는 기능 }\end{array}$ & $\begin{array}{l}\text { 자문, 멘토, } \\
\text { 실행관리 }\end{array}$ & $\begin{array}{c}\text { Rad and } \\
\text { Levin(2002) }\end{array}$ \\
\hline 산출물관리 & $\mathrm{WBS}$ 와 연계된 산출물 버전관리기능 & $\begin{array}{l}\text { 프로젝트관리표 } \\
\text { 준, 방법론 }\end{array}$ & $\begin{array}{c}\text { Dai and } \\
\text { Wells(2004) }\end{array}$ \\
\hline
\end{tabular}

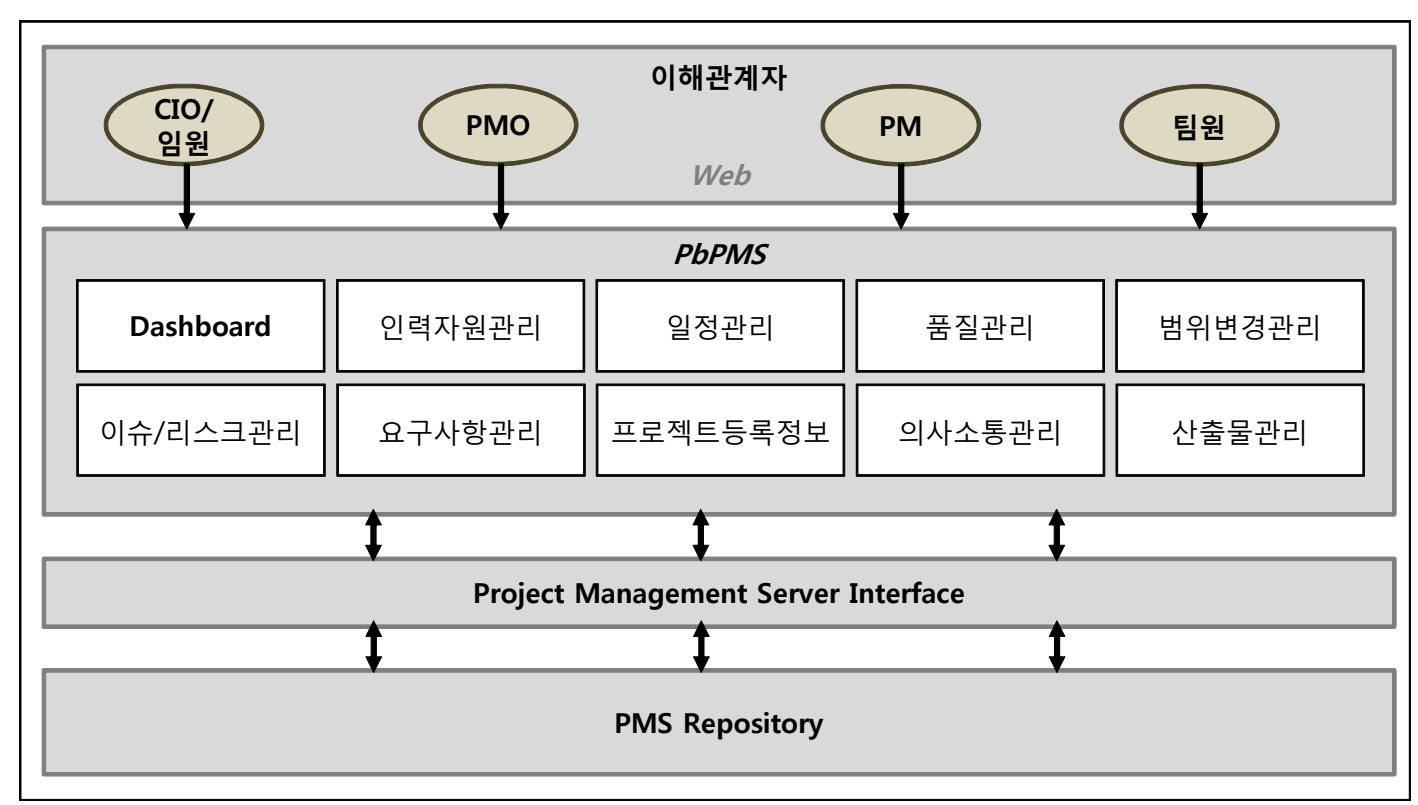

<그림 3>PbPMS 전체 시스템 구성도 
Scope Management, Schedule Management, Quality Management, Risk Management, Human Resource Management, Risk Management, Communication Management, Deliverable Management 기능으로 세분화된다. $\mathrm{PbPMS}$ 는 프로젝트 기획에서 종료 단계까지 체 계적인 프로젝트 관리를 위한 시스템으로, WBS 를 활용하여 프로젝트 진도를 관리하고 프로젝 트 현황에 대한 정보를 실시간으로 제공할 수 있 다. 또한 기존의 인사시스템 및 그룹웨어 등과도 연계하여, 사용자들이 프로젝트와 관련된 업무 를 진행하는 과정에서의 사용자 편의성을 향상 시켰다. 또한 표준화된 인력 관리를 통해 부서변 경, 담당자 변경 시에도 체계적 프로젝트 관리가 가능한 유연한 구조를 갖는다.

\section{2. $\mathrm{PbPMS}$ 설계 프로세스및 산출물}

$\mathrm{PbPMS}$ 의 구축 과정은 일반적인 개발방법론 의 절차인 분석, 설계, 구현, 테스트, 그리고 이행 의 단계를 따른다. <그림 $4>$ 는 이러한 단계 중 테스트 이전 단계인 분석, 설계, 구현 단계의 주 요 산출물을 보여준다. 특히 현업 뿐 아니라 학계 에서도 자주 사용되는 산출물은 이탤릭체로 구 분하여 표시하였으며, 본 절에서는 이들 산출물
(Use Case Diagram, Class Diagram, Context ER Diagram)을 제안 시스템 설계의 대표 산출 물로 소개하고자 한다.

\section{2 .1 요구사항 분석}

대형 정보시스템 개발 프로젝트에는 $\mathrm{CIO}$, $\mathrm{PMO}, \mathrm{PM}, \mathrm{PL}$, 개발자, 현업 담당자 등 다양한 이해관계자들이 참여하게 되므로, 이러한 프로 젝트를 지원하기 위한 PbPMS 설계 과정에서는 이해관계자에 대한 요구분석이 매우 신중하게 이루어져야 한다. 모든 이해관계자들은 상시적 으로 프로젝트에 대한 인식 및 진행 상황을 실시 간으로 공유하기 위해 $\mathrm{PbPMS}$ 를 사용하게 되며, 특히 $\mathrm{PMO}$ 는 $\mathrm{PbPMS}$ 를 활용하여 프로젝트 전반 에 관리 기능을 수행한다. PbPMS의 주요 기능 을 각 이해관계자의 관점에서 파악한 결과가 $<$ 그림 5>에 나타나있다.

$\mathrm{PMO}$ 는 프로젝트 전체 진행사항을 모니터링 하고 이슈/리스크 및 변경 사항에 대한 합의와 승인 프로세스에 직접적으로 참여할 수 있어야 한다. 또한, 최고 의사 결정권자인 $\mathrm{CIO}$ 및 임원 은 Dashboard를 통하여 전체 진행사항을 쉽게 파악할 수 있어야 한다. $\mathrm{PM}$ 은 프로젝트 정보를 시스템에 최초로 등록할 뿐만 아니라, WBS 등

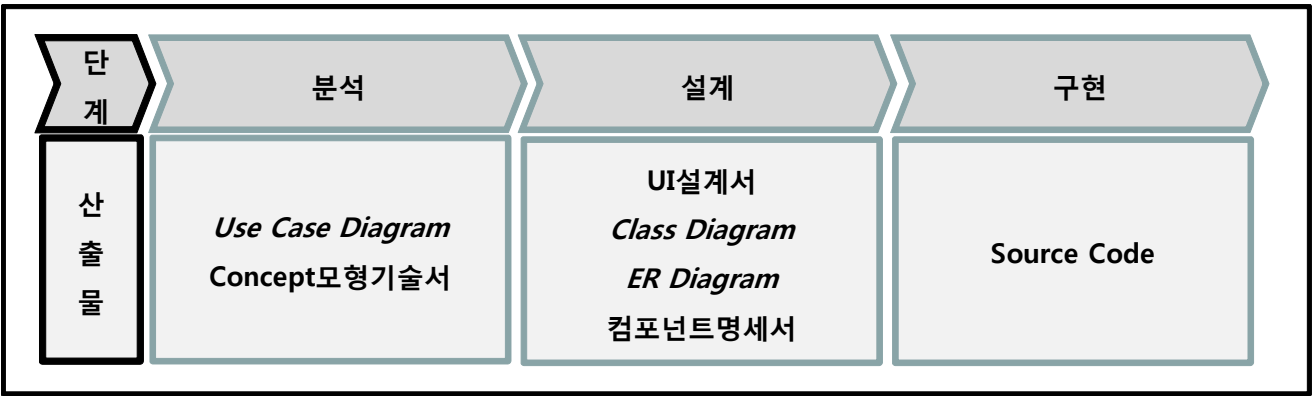

<그림 4> 개발 단계별 주요 산출물 


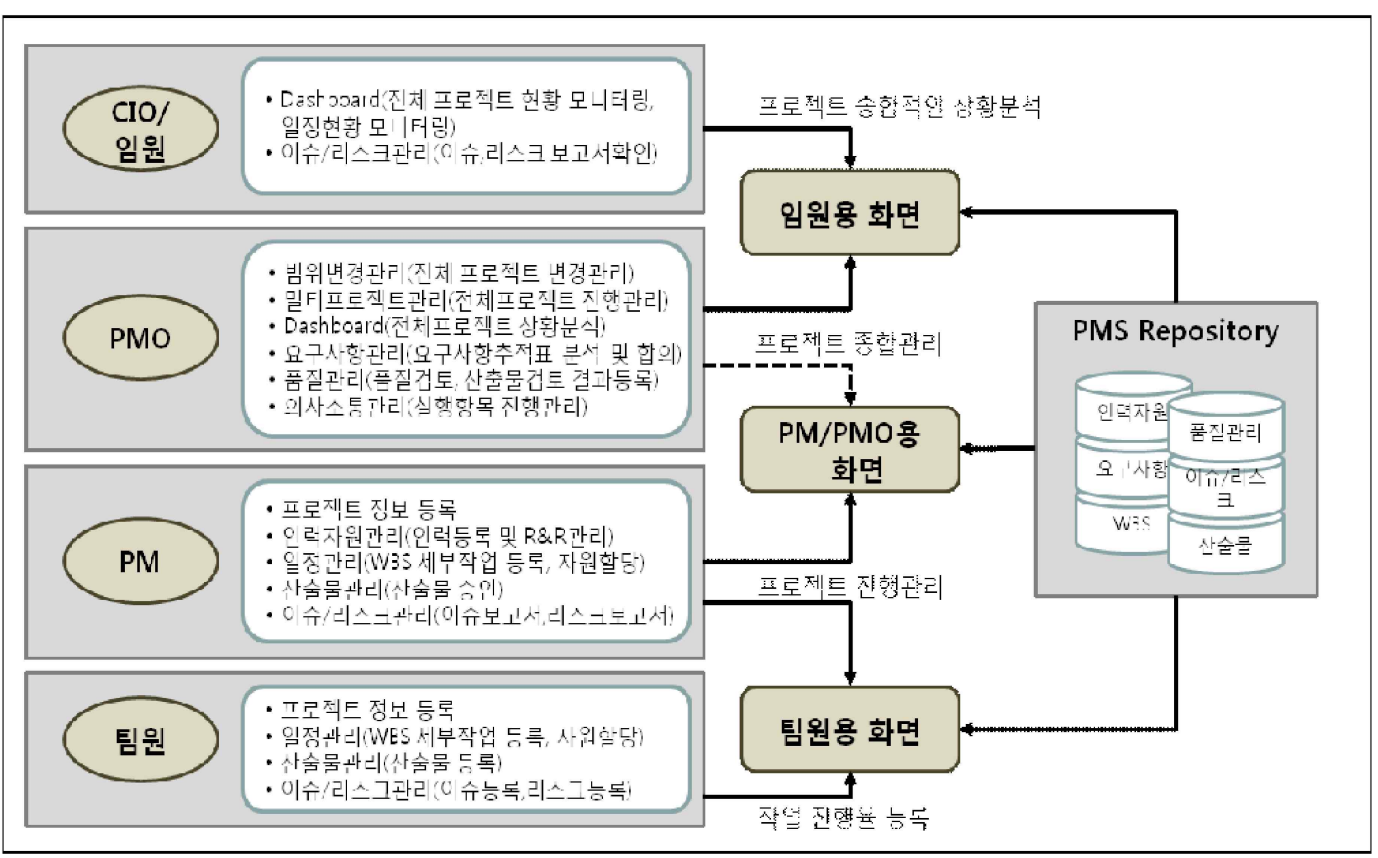

<그림 5>이해관계자의 관점에서 파악한 $\mathrm{PbPMS}$ 의 주요 기능

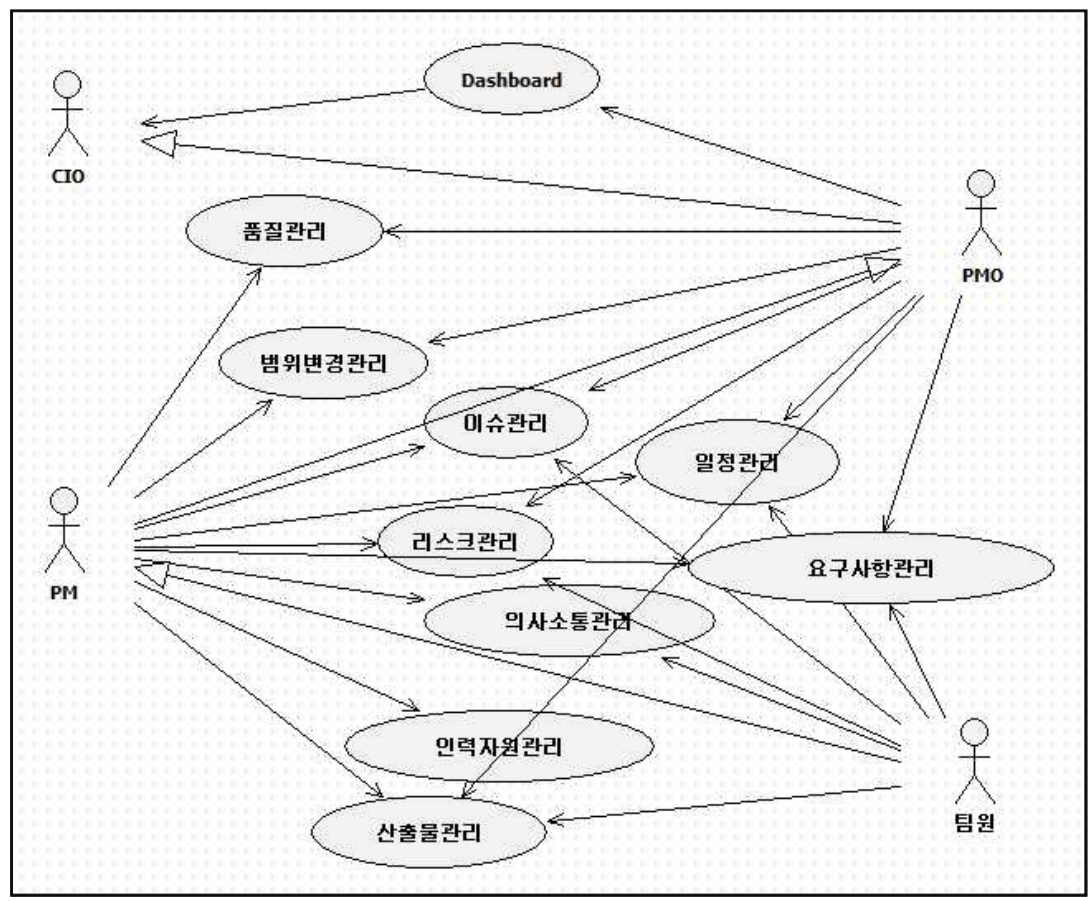

<그림 6>PbPMS를 위한 Use Case Diagram 
록 및 세부작업을 담당할 인력들을 시스템을 통 해 할당한다. 그리고 상시적으로 일정을 모니터 링하며, $\mathrm{WBS}$ 에 대한 진척도를 승인하고 관리할 수 있도록 시스템이 설계되어야 한다. 마지막으 로 개발자인 팀원은 내작업목록(My To Do List) 을 보고 진행상태를 관리할 수 있어야 한다. 이슈 및 리스크는PM 또는 PL뿐 아니라 모든 프로젝 트 참여자가 등록할 수 있도록 설계되어야 한다. <그림 6>은 이러한 요구사항을 실제 시스템 구 현을 위한 수준으로 도출하여 작성한 Use Case Diagram을 보여준다. 그림에서 $\mathrm{CIO}, \mathrm{PMO}, \mathrm{PM}$, Team Member 등 Actor 간에 형성되는 모든 정 보는 Dashboard Use Case를 통해 나타나며, $\mathrm{CIO}$ 와 $\mathrm{PMO}$ 는 이를 통해 전체적인 진행사항을 쉽게 모니터링 할 수 있다. <그림 6>의 Use Case Diagram에 근거하여 도출된 주요 Class에 대한
Class Diagram은 <그림 7>와 같이 나타난다. PbPMS의 Class Diagram<그림 7>에서 프로 그램기본(Program Info.) 클래스는 멀티 프로젝 트를 관리하기 위해 다수의 프로젝트기본 (Project Info.) 클래스와 연결되어 있다. 각 프로 그램에서는 해당되는 프로젝트 정보가 통합 관 리되며, 프로젝트 정보에는 담당 $\mathrm{PMO}$ 의 정보가 포함되어 있다. 인적자원을 관리하기 위한 인력 자원(HR Mgt Info.), 직원(HR Sys Info.) 클래스 는 프로젝트 참여자의 기술등급, 투입기간, 속성 등의 정보를 관리하며, 그 내용은 회사 내부에서 관리하고 있는 $\mathrm{HR}$ 시스템으로부터 정보를 제공 받아 등록된다. 따라서 프로젝트에 관련된 모든 이해관계자는 $\mathrm{PbPMS}$ 를 사용하기 위해 $\mathrm{HR}$ 시스 템에 우선 등록해야 한다. 착수 및 계획단계에서 수립된 프로젝트의 작업계획 정보는 $W B S$ 클래

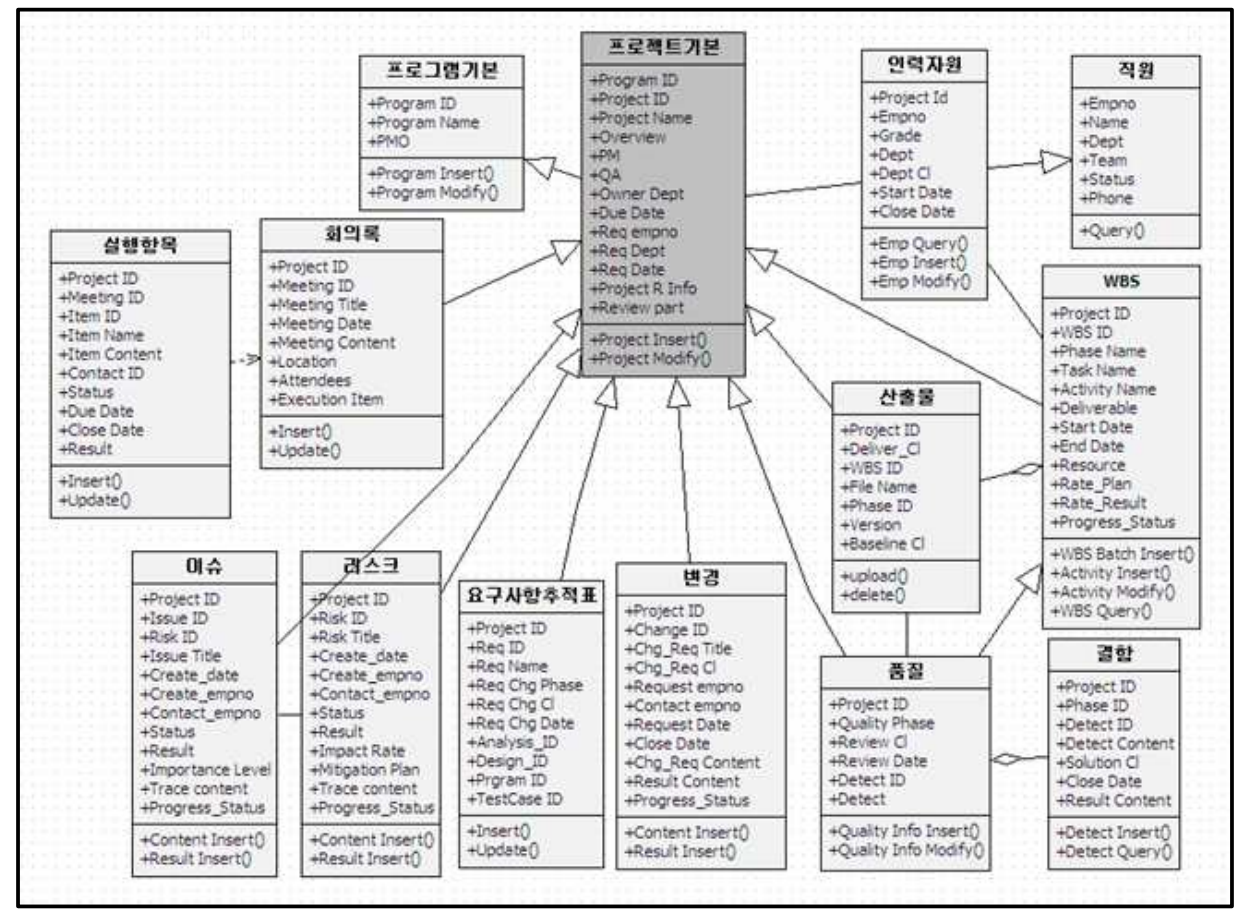

<그림 7>PbPMS의 Class Diagram 
스에서 관리된다. $W B S$ 클래스는 작업 진행사항 의 파악을 위한 기본 정보를 속성으로 가지며, 작업 활동을 등록, 수정, 조회할 수 있다.

프로젝트의 실행 및 통제를 위한 Class들은 품 질 관리, 범위변경 관리, 이슈 및 리스크 관리, 의사소통 관리, 요구사항추적 관리 등의 활동에 사용되며, 각 활동의 결과에 대해 $\mathrm{PMO}$ 가 합의 및 승인할 수 있도록 PMO 승인 속성을 갖고 있 다는 것이 중요한 특징이다. 품질 관리를 위한 품질(Quality Info.) 클래스는 프로젝트 진행단계 마다 단계산출물을 검토하고 그 결과를 등록할 수 있도록 하기 위해 결함정보를 나타내는 결함 (Detect Info.) 클래스와 연계된다. 또한, 일정, 요
구사항, 인력, 또는 형상등에 대해 프로젝트 진행 도중 변경이 이루어진 정보는 범위변경 관리를 위한 변경(Scope Change Info.) 클래스에서 관 리된다. 특히 요구사항의 변경과 관련해서는 요 구사항추적 관리를 위한 별도의 클래스인 요구 사항추적표(Req Matrix Table) 클래스에서 상세 내용을 관리한다. 리스크(Risk Info.) 클래스와 이슈(Issue Info.) 클래스가 서로 연결되어 있는 것은, 리스크 요인은 최초 Risk Info. 클래스에 등록되고 이 리스크가 실제 이슈 요인으로 발전 했을 때 비로소 Issue Info. 클래스에 등록되기 때문이다. 특히 이 두 클래스는, 해당 이슈 및 리스크의 해결을 위해서 일련의 진행상황 등의

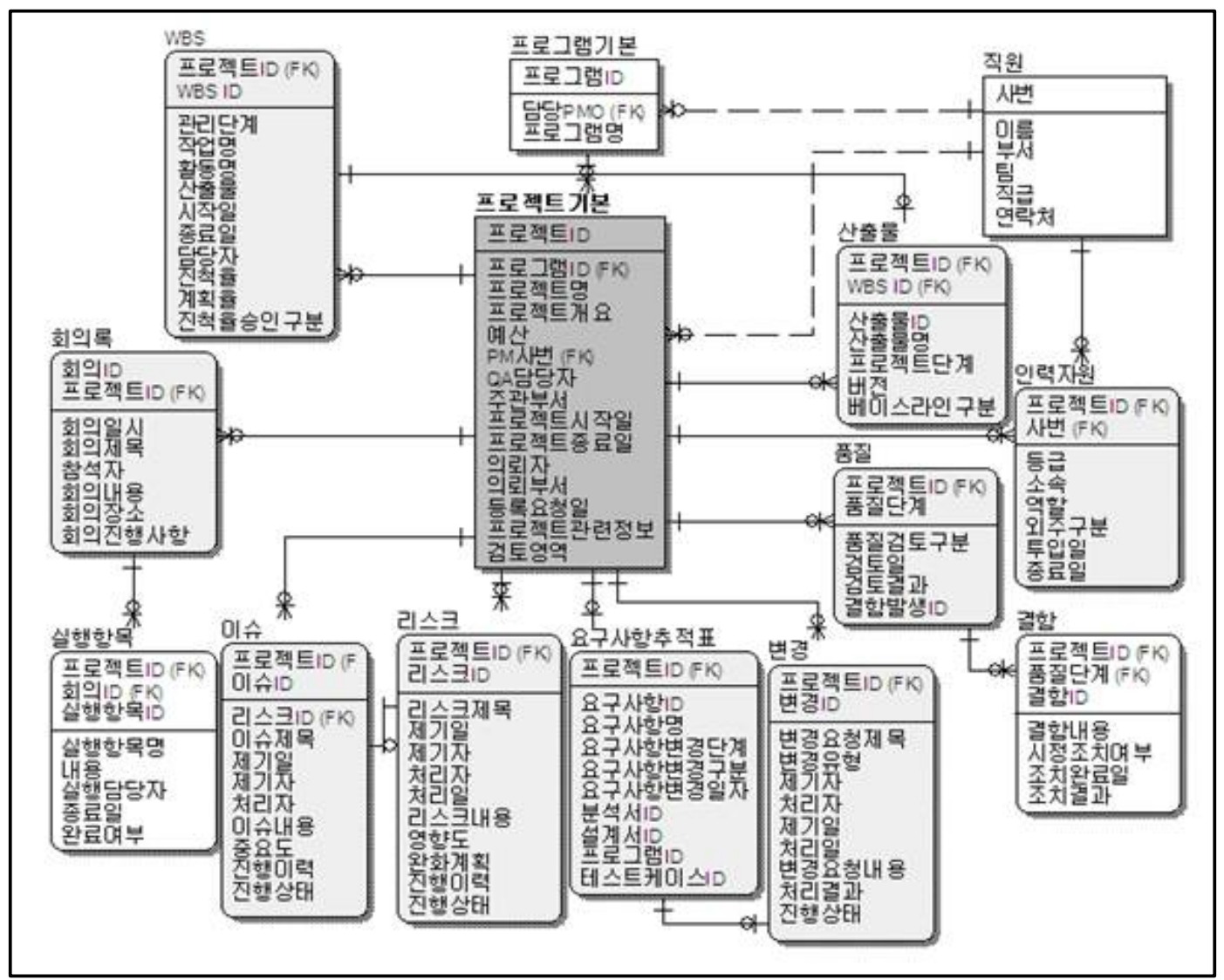

<그림 8> 개념 개체관계도(Context ER Diagram) 
정보를 포함한 속성을 갖고 있다. 의사소통관리 를 위해 모든 회의문서는 회의록(Meeting Report Info.) 클래스에 등록되어 관리되며, 회의 결과로 실행이 확정된 항목들은 추후 진행사항 의 모니터링을 위해 실행항목(Execution Item Info.) 클래스에서 별도로 관리된다.

\subsection{2논리 데이터모델 설계}

본 부절에서는 요구사항 분석의 다음 단계인 논리 데이터모델 설계의 산출물을 살펴본다. 앞 의 부절에서 도출한 Class Diagram의 각 Entity Class는 논리 데이터모델에서 하나의 테이블에 대응되는 것이 일반적이다. 또한 각 Entity Class 의 속성은 논리 데이터모델에서 하나의 데이터 컬럼으로 해석된다. <그림 $8>$ 은 이러한 기본 원 칙에 따라 도출한 $\mathrm{PbPMS}$ 의 논리 데이터모델에 대한 개념 개체관계도를 나타내며, 프로젝트기 본정보 테이블을 중심으로 프로그램기본정보
WBS 정보 인사정보 인력자원정보 품질보증정 보 결함정보 산출물정보 변경관리정보 회의 록정보 실행항목관리, 리스크정보 이슈관리정 보 요구사항추적표 등의 테이블로 구성되어 있 다. 개념 개체관계도는 주요 테이블 및 주요 속성 만을 요약하여 보여준다. 프로그램기본정보 테 이블은 $\mathrm{PMO}$ 에 대한 정보를 담고 있으므로, 각 프로젝트별로 담당 $\mathrm{PMO}$ 를 지정하여 관리할 수 있다. 프로그램기본정보 테이블과 프로젝트기본 정보 테이블은 일대다의 관계를 맺고 있으므로, 각 $\mathrm{PMO}$ 는 여러 프로젝트를 동시에 관리할 수 있음을 나타낸다. 또한 리스크정보 변경관리정 보 테이블의 진행상태 필드는 $\mathrm{PMO}$ 의 승인 및 합의 기능을 구현하기 위한 구분 값을 갖는다.

\subsection{3화면 설계}

본 부절에서는 $\mathrm{PbPMS}$ 를 구성하는 여러 수준 의 화면 중 일부를 소개한다. <그림 9>는 현재

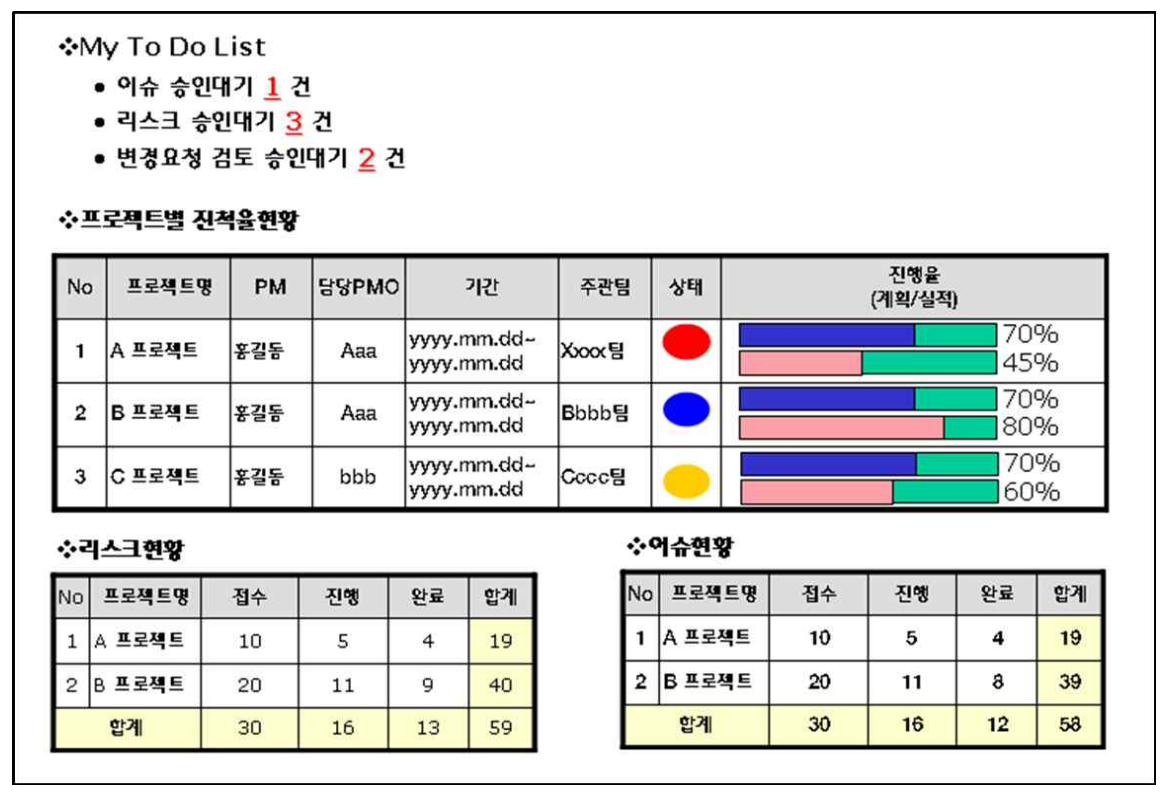

<그림 9>PbPMS의 화면 예 - PMO관리 Dashboard 
진행중인 모든 프로젝트의 진척율과 이슈 및 리 스크 현황을 쉽게 파악할 수 있는 Dashboard 화 면을 나타낸다. Dashboard 화면은 각 프로젝트 별로 담당 $\mathrm{PMO}$, 담당 $\mathrm{PM}$, 전체 진행율의 정보 를 시각적으로 보여준다. 특히 리스크 및 이슈 현황은 모든 내역을 테이블에서 확인할 수 있는 것과 동시에, 담당 $\mathrm{PMO}$ 의 경우 화면 상단의 $\mathrm{To}$ Do List 항목에 자동으로 요약되어 표시됨으로 써 $\mathrm{PMO}$ 의 편의를 도모하였다. 각 프로젝트의 기본정보는 담당 $\mathrm{PM}$ 에 의해 최초 등록되며, 이 를 위한 화면은<그림 $10>$ 에 나타나있다. 하나 의 프로젝트 기본정보 화면은 하나의 프로젝트 에 대한 내용만을 포함하며, 프로젝트의 각 관리 단계에 대한 검토현황 정보를 통합 관리한다. <그림 10>은 사용자가 직접 접하는 화면의 한 예로, 표현된 필드명은 <그림 $8>$ 의 개념 개체관
계도의 속성을 그대로 사용할 수도 있고, 사용자 에게 익숙한 용어로 변형하여 사용될 수도 있다. 또한 일부 필드 값은 여러 속성 값을 조합하여 새롭게 도출되기도 한다.

본 장에서는 $\mathrm{PMO}$ 기반 프로젝트 수행을 효과 적으로 지원하기 위한 $\mathrm{PbPMS}$ 시스템의 설계 및 산출물에 대하여 살펴보았다. 기존 PMS의 경우 $\mathrm{PMO}$ 의 역할과 권한을 고려하지 않고 개발되었 기 때문에, 실제 적용 과정에서는 $\mathrm{PMS}$ 와 수작업 이 병행 사용되는 비효율성이 존재하였다. 반면 본 연구에서 제안하는 $\mathrm{PbPMS}$ 의 경우 기존 $\mathrm{PMS}$ 의 장점을 계승하면서도 $\mathrm{PMO}$ 의 역할과 권한을 반영할 수 있도록 확장 설계되었기 때문에, PMO 의 참여가 전제되는 최근 대부분의 프로젝트 수행 과정에서 기존 $\mathrm{PMS}$ 에 비해 실질적이고 효과적인 지원도구 역할을 할 수 있을 것으로 기대된다.

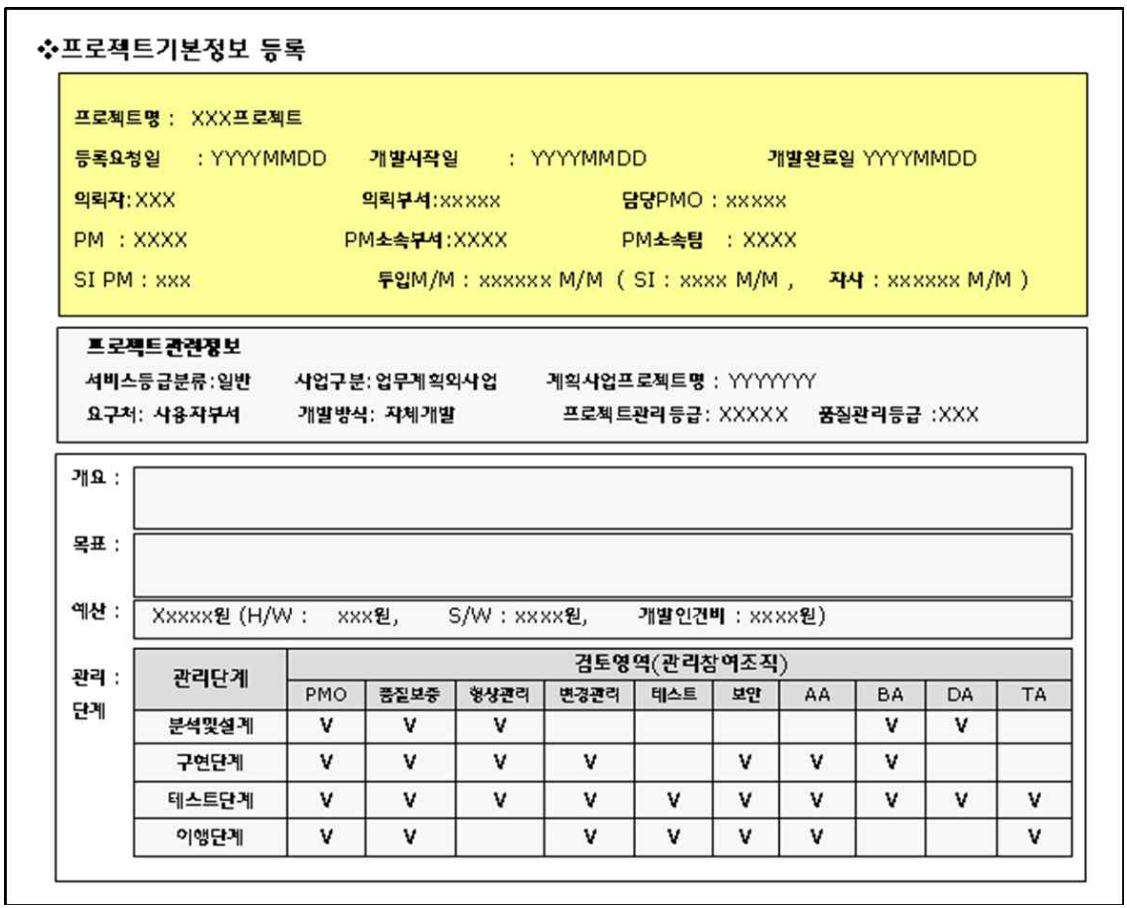

<그림 $10>\mathrm{PbPMS}$ 의 프로젝트 기본정보등록 화면 
IV. 사례 분석-“K”은행 차세대 시스템 구축

본 장에서는 본 연구에서 제안하고 구축한 $\mathrm{PMO}$ 기반 PMS의 현장 적용 사례를 소개하고 분석하고자 한다. 사례 대상 기업은 기존 $\mathrm{PMS}$ 를 이미 보유하고 있었으나, 본문에서 이미 논의한 여러 한계로 인해 차세대 시스템 구축 프로젝트 추진에 어려움을 갖고 있었다. 이러한 배경에서 이 기업은 차세대 시스템 구축을 위해 $\mathrm{PMO}$ 를 미리 조직하였으며, 차세대 시스템 구축 프로젝 트가 본격적으로 시작되기 전에 본 연구에서 제 안한 $\mathrm{PbPMS}$ 의 주요 모듈을 확장하여 통합품질 관리시스템(Integrated Quality Management System: IQMS)을 구축하였다. IQMS는 실제 차 세대 시스템 구축 프로젝트에서 프로젝트 관리 지원을 성공적으로 수행한 것으로 평가되고 있 다. 본 장의 첫 절에서는 사례의 개요를 간략히 소개하고, 4.2 절에서는 차세대 시스템 구축의 사전 프로젝트로 수행된 IQMS 구축의 결과를 소개한다. 마지막 절인 4.3 절에서는 IQMS를 적 용한 차세대 프로젝트의 성과를 주요 지표 위주 로 평가한다.

\section{1 사례 개요}

본 사례연구의 대상 기업인 "K"은행은 2011 년6월 기준 전국에 약 1,000 개의 지점을 갖고 있으며 종업원 약 26,000 명이 근무하는 대형 금 융기관이다. "K"은행의 주요 업무는 수신 및 여 신업무, 외국환 업무, 신탁업무, 직불카드발급업 무 등이며, 신속한 상품 출시 및 상품 요건 변경 처리가 가능해야 한다는 비즈니스 요구를 충족
시키기 위해 차세대 시스템 구축 프로젝트를 추 진하게 되었다. 또한 " $\mathrm{K}$ " 은행은 차세대 시스템 구축을 통해 인터넷, 폰 뱅킹, 모바일뱅킹, $\mathrm{TV}$ 뱅킹 등의 비대면 거래 채널 다양화를 추구하였 으며, IT 운영 측면에서는 이기종 시스템 간의 호환성을 높임으로써 특정 벤더에 종속되지 않 고 $\mathrm{SW}$ 와 $\mathrm{HW}$ 를 유연하게 도입할 수 있는 환경 을 만들고자 하였다. 이러한 목표를 달성하기 위 해 구체적으로, 계정계 시스템 재구축, 다중 채널 통합(MCI) 시스템 구축, 전행 인터페이스 통합 시스템 구축, 전사적 데이터웨어하우스(EDW) 시스템 구축, 경영정보시스템(정보계)재구축, 인 터넷 뱅킹재구축 등의 작업을 수행하였으며, 전 체 프로젝트는2008년 9월부터 2010년2월까지 단계별로 진행되었다.

한편 차세대 프로젝트를 효율적으로 관리하 기 위하여 본격적인 차세대 프로젝트 시작 전에 $\mathrm{PMO}$ 기반의 프로젝트 관리를 실질적으로 지원 할 수 있는 확장된 형태의 $\mathrm{PMS}$ 를 구축해야 할 필요성이 대두되었다. 보유하고 있던 기존 PMS 는 다양한 요구사항 수용이 어려우며 프로젝트 관리영역간 연계가 용이하지 않고, $\mathrm{PMO}$ 의 모니 터링 및 조정기능이 취약하여 차세대 시스템의 품질관리를 효과적으로 수행하기 어려운 실정이 었다. 이러한 배경으로부터 기존 $\mathrm{PMS}$ 의 기능을 확대, 강화하고 차세대 시스템의 품질관리 기반 을 마련하는 동시에 시스템 복잡화에 대한 체계 적인 관리를 지원하기 위해 PMO 기반의 PMS 를 구축하기 위한 프로젝트가 진행되었다. 추진 범위는 프로젝트관리, 요구사항관리, 변경관리, 품질보증/검토 및 지원업무 부문등이며, 차세대 가 본격적으로 시작되기 전인 2007년 10월부터 2008년 9월까지 총 11 개월에 걸쳐 진행되었다. 


\section{2 “ $\mathrm{K}$ ” 은행 통합품질관리시스템}

"K" 은행의 IQMS 구축을 위해 우선 기존의 상용 PMS제품을 비교 분석하였으며, 본 연구에 서 제안한 $\mathrm{PbPMS}$ 의 주요 기능 위주로 전체 프 레임워크를 구성하였다. 구축한 시스템의 전체 메뉴는 프로젝트 진행 흐름에 따라 구성되었으 며 <그림 11>에 나타나있다.

착수관리메뉴에서는 프로젝트 정보 등록, WBS 작성, 프로젝트 착수 계획 수립 등의 기능 을 수행하며, 프로젝트 관리 영역인 진행관리 메 뉴에서는 진척관리, 이슈관리 등을 수행한다. 단 계말관리 메뉴의 핵심 기능은 프로젝트 단계별 검토 기능이며, 추가적으로 테스트/이행관리 메 뉴를 두어 테스트 결과 조회, 이행 및 상황실 관 리를 가능하게 하였다. 마지막으로 의사소통을 지원하기 위해 게시판관리, 회의관리 등의 메뉴 를 설계하였다. 전체 메뉴 중 검토에 해당되는 다수의 메뉴는 기존 PMS의 한계인 $\mathrm{PMO}$ 의 모 니터링 및 조정기능을 강화하기 위한 기능을 나 타낸다. 한편 요구사항 관리는 영업점에서의 접 속이 용이하도록, 메인 화면 외부에 별도의 메뉴
로 구성하였다.

개발프로젝트 관리를 위한 메인 화면은 <그림 $12>$ 와 내가 할일(My To List)과 $\mathrm{PMO}$ 를 위한 타프로젝트 관리 탭으로 구성되어 있다. <그림 $13>$ 은 $\mathrm{PMO}$ 의 주요 활동 중의 하나인 단계말 검토 활동을 위한 화면을 보이고 있다. $\mathrm{PMO}$ 는 각 단계말에 관련 산출물의 진행사항을 점검하 기 위해 검토영역별 검토자를 선임하여 검토를 실시하고, 그 결과를 시스템에 등록한다. <그림 $13>$ 의 화면 구성을 사용 시나리오를 통해 설명 하면 다음과 같다. (1) 각 검토영역별 검토자를 등록한다. (2) 저장 버튼을 클릭하여 변경된 검토 자 정보를 저장한다. (3) 검토의뢰 버튼을 클릭하 여 검토 담당자에게 검토의뢰 한다. (4) 검토 담 당자는 검토서를 등록한다. (5) 검토 담당자가 검토서를 등록하면, 승인자는 승인상태를 수정 한 후 저장한다. (6) 검토 담당자는 산출물 보기 버튼을 클릭해서 산출물을 확인한다. (7) 검토 담당자는 검토항목 보기 버튼을 클릭해서 검토 항목을 확인한다.

\begin{tabular}{|c|c|c|c|c|}
\hline 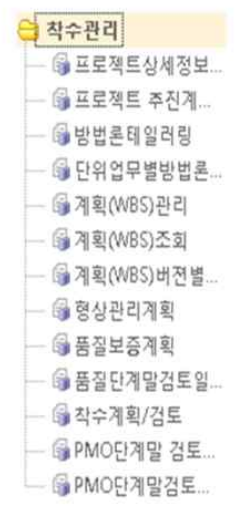 & 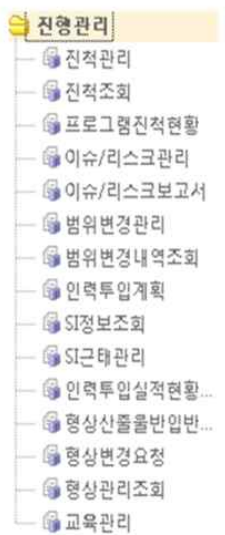 & 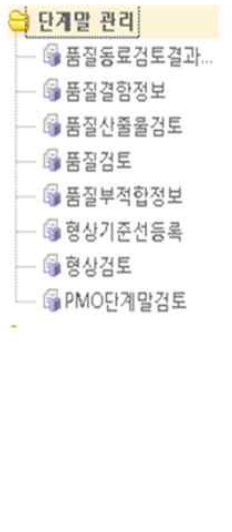 & 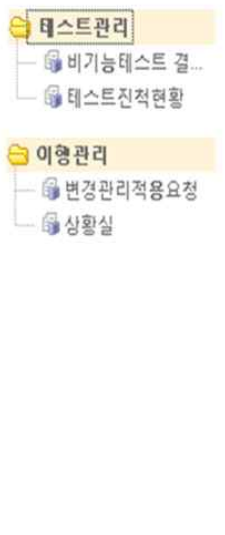 & $\begin{array}{l}\frac{9 \text { 기핀관리 }}{1 \text { 게시판 }} \\
\text { 회의관리 } \\
\text { - 회의록관리 } \\
\text { 실행항곡란리 }\end{array}$ \\
\hline
\end{tabular}

<그림 11> "K" 은행 통합품질관리시스템 전체 메뉴 구성 
$\mathrm{PMO}$ 기반 프로젝트 관리 시스템의 설계 및 적용

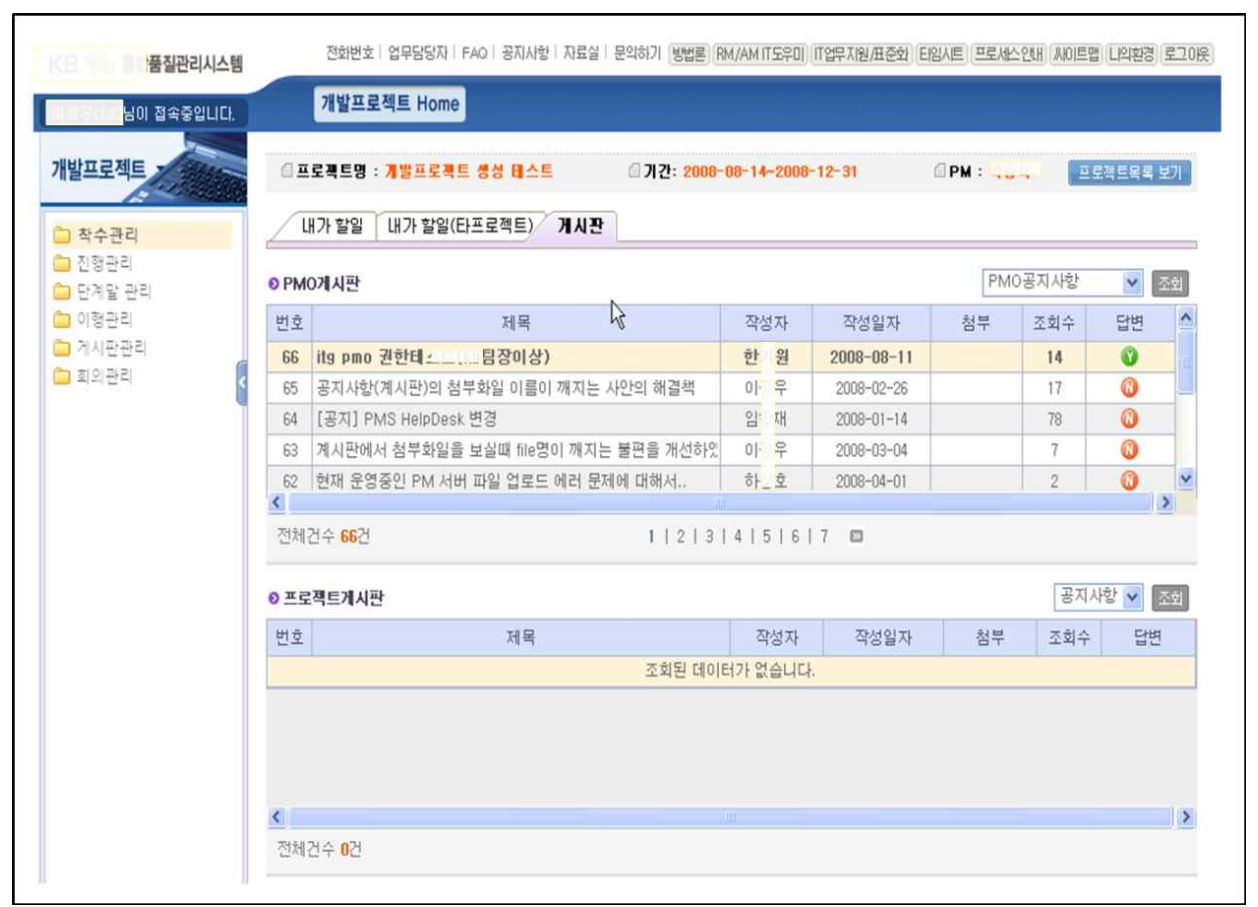

<그림 12>개발프로젝트관리 메인화면

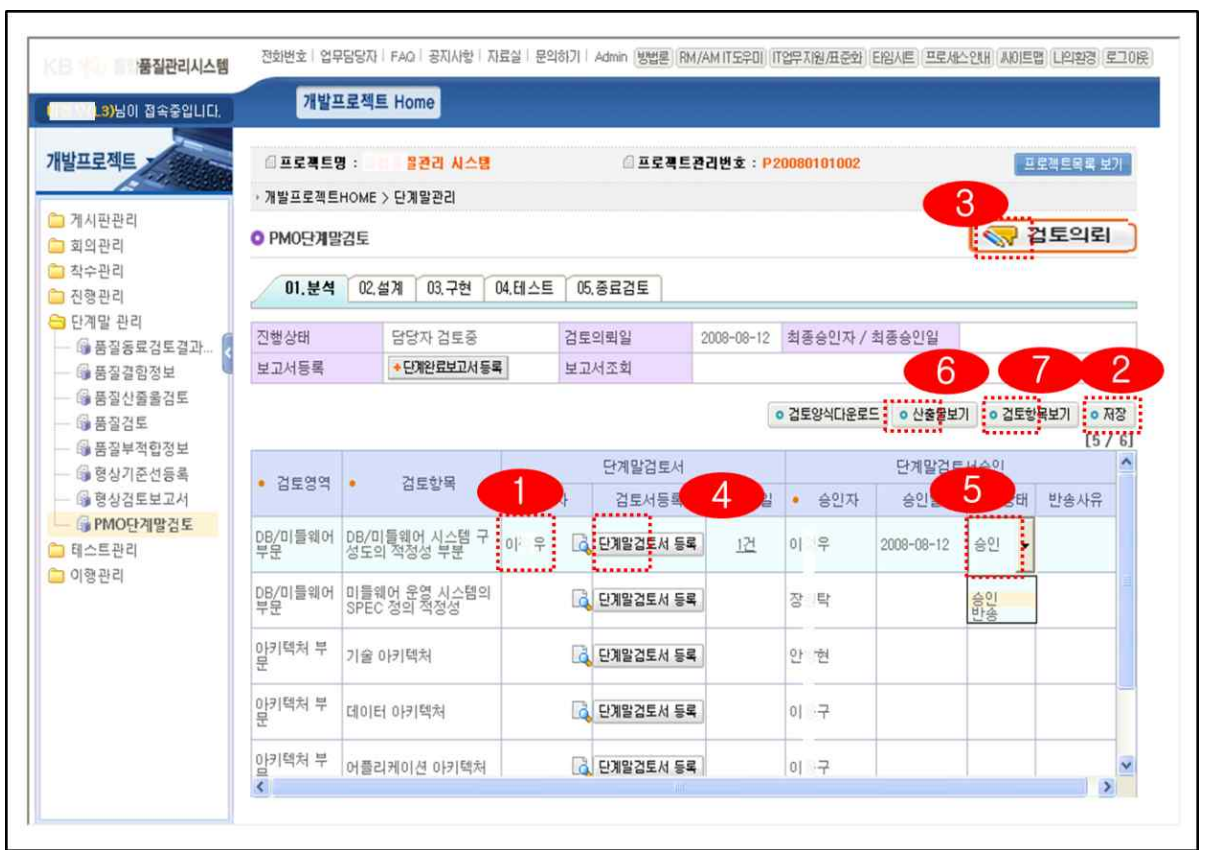

<그림 13> PMO의 단계말 검토 화면 
본 절에서는 "K"은행의 $\mathrm{PMO}$ 기반 프로젝트 관리를 위해 구축된 통합품질관리시스템의 주요 화면을 기능 위주로 소개하였다. 이 시스템은 구 축된 이후의 다수 프로젝트의 관리에 활용되었으 며, 그 성과에 대한 평가는 다음 절에서 소개한다.

\section{3 “ $\mathrm{K}$ ” 은행의 통합품질관리시스템 활} 용 성과 평가

"K" 은행의 PMO 기반 PMS인 IQMS는, 구축 된 이후 "K" 은행의 주요 프로젝트에서 활발하 게 사용되었다. <그림 $14>$ 에 포함된 전체 13 개 의 차세대 프로젝트 가운데, 2 단계 프로젝트 중 차세대 PMS 구축 프로젝트를 제외한 4개의 차 세대 프로젝트(1. 계정계 시스템 재구축, 5. 차세 대 단말/자동화 시스템, 7. 경영정보시스템 구축, 10. 인터넷뱅킹재구축)의 관리도구로 IQMS가
사용되었다. 특히 차세대 1단계 프로젝트가 차세 대구축을 위한 기반성 프로젝트였다면 2단계는 은행에서 중요도가 높은 계정계, 정보계 업무들 로 구성이 되어 있다는 측면에서, 고객사의 모든 역량이 프로젝트에 집중되어 있는 상황이었다. 프로젝트가 본격적인 구축 단계에 진입한 이후 에는 프로젝트의 단계별 산출물에 대한 $\mathrm{PMO}$ 의 품질검토, 일정 및 진척에 대한 진행관리와 설계, 테스트, 데이터 이행등에 대한 관리의 중요성이 더욱 강조되었다. 따라서 IQMS의 일부 기능은 차세대 2단계가 시작되는 시기부터 적용된 경우 도 있었으며, IQMS의 완성 이후에는 4개의 대 상 프로젝트의 진행단계에 맞춰 유연하게 적용 되었다.

$\mathrm{PMO}$ 기반의 PMS를 적용한 4개의 프로젝트 의 진행결과는 <표 $6>$ 와 같다. <표 $6>$ 에서 납기 준수 여부는 계획된 납기일과 실제 종료일을 기

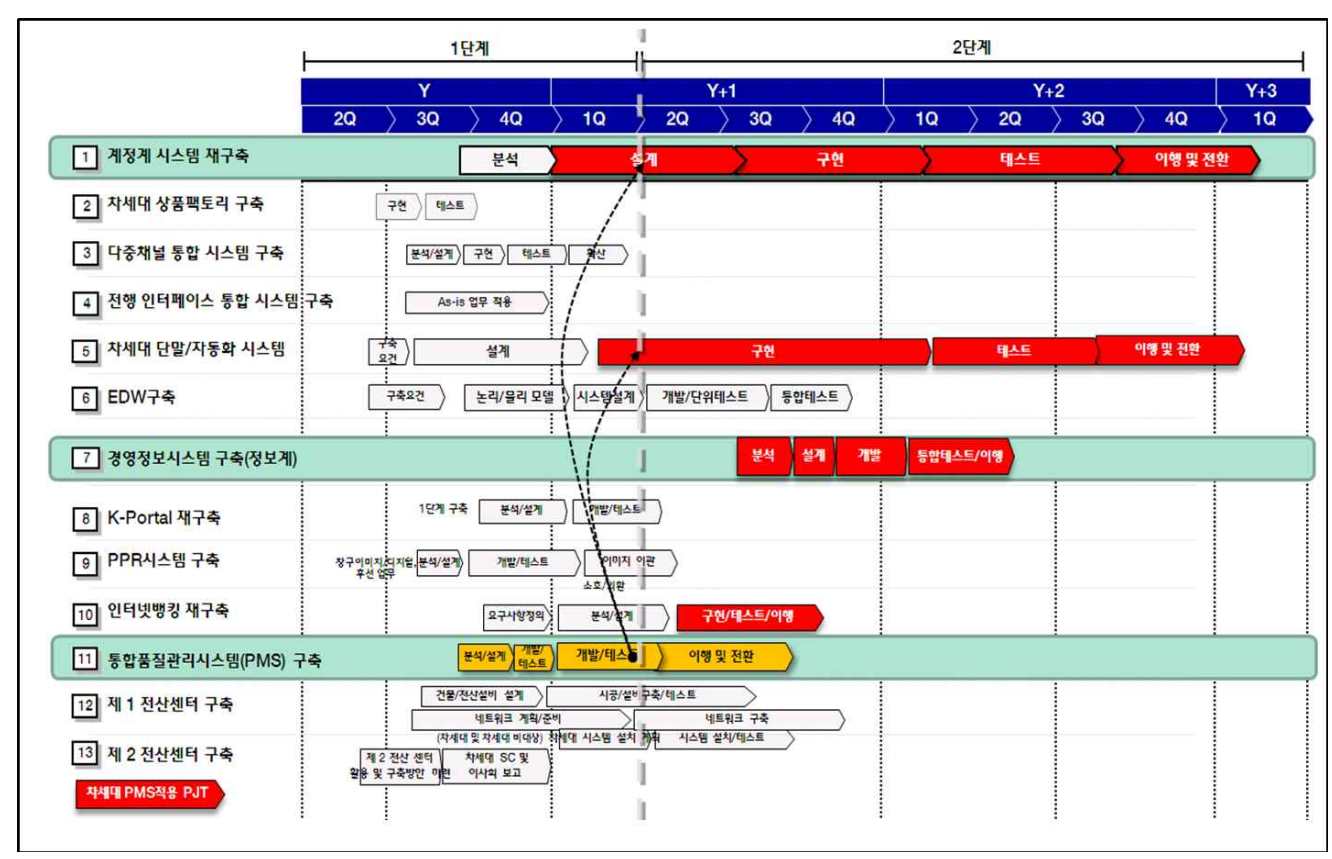

<그림 14>"K"은행 IQMS의 차세대프로젝트적용 현황 
준으로 점검하였다. 오픈일은 계약종료일 대비 시스템 오픈일을 의미한다. 또한 품질은 Review 와 Inspection의 두 가지 관점에서 점검되며, 각 각 적정, 보통, 미흡, 부적정의 네 단계로 평가된 다. 비용의 경우 프로젝트 계약금액을 기준으로 추가비용이 발생하였는지의 여부를 측정한다. IQMS를 적용한 첫 프로젝트인 인터넷뱅킹재구 축 프로젝트는 구현 단계초반부터 IQMS가 적용 되었으며 $\mathrm{WBS}$ 일정관리와 이행관리위주로 진 행되었다. 이 프로젝트는 한 번의 클릭으로 계좌 이용이 가능하며 개인별 맞춤 서비스 제공이 가 능한 시스템을 구축하는 프로젝트로, 새로운 시 스템은 매번 홈페이지에 접속하지 않고 아이콘 클릭만으로도 인터넷뱅킹 거래를 할 수 있는 위 젯서비스를 제공하여, 즉시 계좌조회와 이체업 무 처리가 가능하도록 하였다. 이 프로젝트는 계 획된 기간 내에 비용의 초과 집행 없이 수행되었 으며, 품질에 대해서도 적정 판정을 받은 성공적 인 프로젝트로 평가되고 있다. 한편 정보계 프로 젝트인 경영정보시스템구축 프로젝트는, 차세대 IT표준아키텍처와 차세대 금융단말 시스템 및 $\mathrm{MCI}, \mathrm{EAI}$ 등을 적용, $\mathrm{UNIX}$ 기반 오픈환경으로 개발되었다. 경영정보시스템 개선을 통해 온라
인거래의 응답속도가 크게 향상되었으며, UXB(User eXperience for Business)방법론을 적용한 UI 구현으로 사용자 편의성도 크게 높아 진 것으로 나타났다. 이와 동시에 정보계시스템 의 주요과제인 배치작업 처리시간이 획기적으로 단축되어 정보 전달의 신속성이 크게 향상되었 다. 마지막으로 3 년간의 준비 기간을 가진 차세 대 전산시스템은 차세대 단말/자동화 시스템과 계정계 시스템의 완성을 마지막으로 본격적인 서비스를 개시하였다. 차세대시스템의 구축을 통해 수신 및 여신 등계정계와 신용카드, 방카슈 랑스, 퇴직연금 등 여러 개의 단말거래를 하나로 통합해 업무처리 절차를 단순화 함으로써 고객 의 대기시간을 단축시킬 수 있었다. 이상 언급한 모든 프로젝트는 적정 품질을 준수하며 계획된 납기와 비용 내에서 성공적으로 완료되었으며, 완료된 프로젝트의 반 이상이 최초 예상 비용의 $189 \%$ 이상을 지출하고, 1 년 이상의 장기 프로젝 트 중에서 최초 계획된 일정의 두 배 이상의 기간 이 소요된 프로젝트도 $35 \%$ 이상인 것으로 나타 난 기존의 연구 결과에 비추어볼 때, PMO 기반 의 $\mathrm{PMS}$ 에 의한 프로젝트 수행은 매우 성공적인 것으로 평가될 수 있다.

<표6> PMS적용 프로젝트 진행결과

\begin{tabular}{|c|c|c|c|c|c|c|c|}
\hline \multirow{2}{*}{ NO } & \multirow{2}{*}{$\begin{array}{c}\text { 차세대 } \\
\text { 프로젝트명 }\end{array}$} & \multicolumn{3}{|c|}{ 납기준수 } & \multicolumn{2}{|c|}{ 품질 } & \multirow{2}{*}{$\begin{array}{l}\text { 비용준수 } \\
\text { 추가비용 }\end{array}$} \\
\hline & & 계획 & 종료 & 오픈일 & Review & Inspection & \\
\hline 10 & $\begin{array}{c}\text { 인터넷뱅킹 } \\
\text { 재구축 }\end{array}$ & 14 개월 & 14 개월 & D-23 & 적정 & 적정 & 미발생 \\
\hline 7 & $\begin{array}{c}\text { 경영정보시스템구축 } \\
\text { (정보계) }\end{array}$ & 10.5 개월 & 10.5 개월 & D-18 & 적정 & 적정 & 미발생 \\
\hline 5 & $\begin{array}{l}\text { 차세대 단말/ } \\
\text { 자동화 시스템 }\end{array}$ & 33개월 & 33개월 & D-10 & 적정 & 적정 & 미발생 \\
\hline 1 & 계정계시스템 재구축 & 20개월 & 20개월 & D-2 & 적정 & 적정 & 미발생 \\
\hline
\end{tabular}




\section{$\mathrm{V}$. 결 론}

최근 금융권의 차세대 시스템 구축 프로젝트 를 중심으로 정보시스템 개발 프로젝트가 대형 화, 복잡화됨에 따라, 많은 기업들이 복잡한 다수 의 프로젝트를 효과적으로 관리하기 위한 전담 조직인 $\mathrm{PMO}$ 를 도입하여 운영하고 있다. $\mathrm{PMO}$ 기반으로 수행된 프로젝트의 경우 다른 프로젝 트에 비해 납기준수율, 비용준수율, 품질 등이 우수하게 나타나는 등, $\mathrm{PMO}$ 기반 프로젝트 수 행의 효과 및 당위성은 많은 연구와 사례에서 입 증되고 있다. 하지만 $\mathrm{PMO}$ 기반으로 프로젝트를 수행하는 환경에서도, 프로젝트 관리 지원을 위 한 도구인 프로젝트관리시스템(PMS)는 여전히 소규모 단일 프로젝트 위주로 개발된 기존의 제 품을 사용함으로써, 지원 도구와 실제 프로젝트 운영 방식 간의 차이로 인해 오히려 비효율이 발 생하는 경우가 존재한다. 따라서 본 연구에서는 $\mathrm{PMO}$ 기반의 프로젝트를 효과적으로 지원하기 위한 $\mathrm{PMS}$, 즉 $\mathrm{PMO}$ 의 권한과 역할이 충실히 반 영된 $\mathrm{PMS}$ 를 설계하고 구축하였다. 또한 구축된 시스템을 실제 프로젝트 관리에 적용한 " $\mathrm{K}$ " 은 행의 사례를 소개함으로써, 제안 시스템의 현업 적용 가능성을 제시하였다.

본 논문의 연구 성과를 요약하면 다음과 같다. $\mathrm{PMO}$ 기반으로 수행되는 프로젝트 환경과 이를 지원하는 기존 PMS 간의 차이로 인한 비효율성 을 지적하였다. 이를 통해 많은 개발 업체들이 기존 PMS의 확장 또는 전면 재구축을 통해, $\mathrm{PMO}$ 의 활동을 효과적으로 지원할 수 있는 PMS 개발에 참여하게 될 것으로 기대한다. 또한 $\mathrm{PMO}$ 기반 $\mathrm{PMS}$ 의 기능 및 주요 설계 산출물을 소개함 으로써, 향후 $\mathrm{PMO}$ 기반 $\mathrm{PMS}$ 를 구축하고자 하
는 기업이 참조할 수 있는 설계 모델을 마련하였 다. 마지막으로 본 연구에서 제안된 시스템을 프 로젝트 관리에 성공적으로 적용한 실제 사례를 소개함으로써, 이미 $\mathrm{PMO}$ 를 조직하여 운영하고 있는 기업에게 PMO 기반 PMS 도입의 효과 및 당위성을 제시한 점도 기여로 인정될 수 있을 것 이다.

본 연구의 후속 연구에서는 다음과 같은 측면 의 보완이 이루어져야 한다. 우선 제안한 시스템 은 다수의 프로젝트를 동시에 관리하는 시스템 이므로, 실제 서비스 제공 시 시스템 처리 속도 등에 대한 면밀한 분석이 필요하다. 또한 최근 활발히 보급되고 있는 다양한 모바일 기기용 애 플리케이션 제작을 통해, $\mathrm{PC}$ 를 통해 인터넷에 접속하기 어려운 환경에서도 $\mathrm{PMO}$ 에게 프로젝 트의 다양한 현안에 대한 실시간 정보를 제공할 수 있는 방안을 마련할 수 있을 것이다. 마지막으 로, 본 논문에서 소개한 실제 사례는 금융업에 속한 특정 회사의 정보시스템 개발 프로젝트에 국한된 사례이므로, 이 결과를 전체 산업 분야 전체 프로젝트로 일반화하기에는 무리가 있다. 따라서 향후 다양한 산업 분야에 대한 특성 반영 및 연구를 통해, 본 논문에서 제안하는 시스템의 설계가 수정 보완될 필요가 있다.

\section{참고문헌}

김상열, 김승윤, 이재범, "PMO 관점에서 본 정 보시스템 개발 프로젝트 주요성공요인 에 관한 연구," 대한산업공학회/한국경 영과학회 춘계공동학술대회, 2004.

김상열, 장윤희, “정보시스템 개발 프로젝트 성 
과 향상을 위한 $\mathrm{PMO}$ 핵심 기능과 관리 수준에 관한 연구: 금융권 차세대 프로 젝트 사례를 중심으로," 정보시스템연 구, 제 15 권, 제4호, 2006, pp.1-22.

김석훈, 정진영, 안우영, "MIS 환경에서의 중소 기업형 프로젝트 성과관리 시스템," 한 국항행학회논문지, 제13권, 제6호, 2009, pp.964-970.

김희영 ““연구개발 프로젝트관리시스템(PMS)의 개발 및 구현에 관한 연구," 석사학위논 문, 한양대학교 대학원, 2008.

옹상순, 최재현, 박제원, 이남용, "UML기반의 공공부문 정보화 프로젝트관리 모델에 관한 연구," 한국IT서비스학회지, 제8 권, 제3호, 2009, pp.101-109.

정철용, 손동기, “AHP 기법을 활용한 정보시스 템 개발 프로젝트 위험요인 평가에 대한 탐색적 연구," 정보시스템연구, 제 15 권, 제2호, 2006, pp.77-93.

조재성, 박주철, “소규모 IT 업체를 위한 프로젝 트 일정 관리 시스템 개발에 관한 연구," 대한산업공학회/한국경영과학회 춘계 공동학술대회, 2008.

홍사능, "대규모 프로젝트의 위험요인과 위험관 리에 관한 사례연구," 정보시스템연구, 제19권, 제1호, 2010, pp.97-116.

PMI, “프로젝트관리 지식체계 지침서 (PMBOKâ Guide)," 제3판, Project Management Institute, Inc., 2004.

BIA, The Impact of Implementing a Project Management Office-Report on the Results of the On-Line Survey, Research Report, Business
Improvement Architects, 2005.

Chase, R. B., and Stewart, D. M., "Make Your Service Fail-Safe," Sloan Management Review, Vol.35, No.3, 1994, pp.35-44.

Dai, C. X., and Wells, W. G., "An Exploration of Project Management Office Features and Their Relationship to Project Performance," International Journal of Project Management, Vol.22, No.7, 2004, pp.523-532.

Hill, G. M., "Evolving the Project Management Office: A Competency Continuum," Information Systems Management, Vol.21, No.4, 2004, pp.45-51.

Orlikowski, W. J., "Division among the Ranks: The Social Implications of CASE Tools for Systems Developers," in Proc. $10^{\text {th }}$ International Conference on Information Systems, Boston, MA., 1989.

Orwig, R. A., and Brennan, L. L., "An Integrated View of Project and Quality Management for Project-Based Organizations," International Journal of Quality \& Reliability Management, Vol.17, No.4/5, 2000, pp.351-363.

Parasuraman, A., Zeithaml, V. A., and Berry, L. L., "Refinement and Reassessment of the SERVQUAL Scale," Journal of Retailing, Vol.67, No.4, 1991. pp.420-450.

Rad, P. F., and Levin, G., The Advanced Project Management Office: A Comprehensive Look at Function and Implementation, 
CRC Press, 2002.

Rai, A., and Howard, G. S., "An Organizational Context for CASE Innovation," Information Resources Management Journal, Vol.6, No.3, 1993, pp.21-35. Rai, A., and Patnayakuni, R., "A Structural Model for CASE Adoption Behavior," Journal of Management Information Systems, Vol.13, No.2, 1996, pp. 205-234.

Ruso, N. L., The Impact of Context on Innovation in Information Systems, Ph.D. Dissertation, Georgia State University, 1993.

The Standish Group International Inc., The Standish Report, The Standish Group International, Inc., 2006.
정천수(Jeong, Cheon-Su)

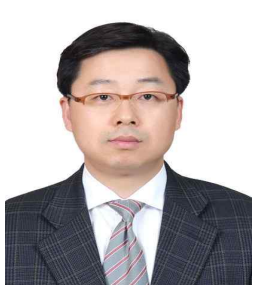

고려대학교에서 컴퓨터공 학전공으로 석사를 마쳤으며, 현재 국민대학교 비즈니스IT 전공 박사과정 중에 있다. $\mathrm{KB}$ 국민은행, 대구은행 등 다수의 금융권 차세대 프로젝트에 참 여하였으며, 주요 연구 관심분 야는 대형 IS 프로젝트 관리, $\mathrm{PMO}$, 프로젝트 의사소통 관리, 정보시스템개발 등이다.

\section{김승렬(Kim, Seung-Ryeol)}

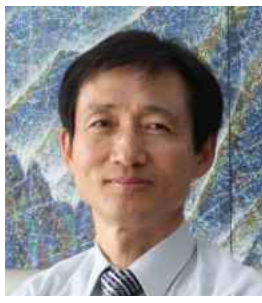

현재 국민대학교 경영정보 학부에서 교수로 재직 중이 다. 서울공대 응용수학과에서 학사, 대학원 산업공학과에서 석사학위를 취득하였다. 대한 항공 MIS실에서 근무한 후 미국 Iowa 주립대학에서 박 사학위를 취득하였다. 캘리포니아 주립대학교(SLO) 에서 교수로 재직 후 귀국하여 한국경영과학회, 한국 정보과학회에서 활동 중이다. 관심 분야는 시스템 분 석 및 설계, 소프트웨어 공학 등이다.

\section{김남규(Kim, Nam-Gyu)}

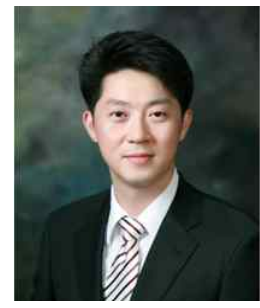

현재 국민대학교 경영정보 학부에서 조교수로 재직 중이 다. 서울대학교 컴퓨터공학과 에서 학사 학위를 취득하고, KAIST 테크노경영대학원에 서 Database와 MIS를 전공하 여 경영공학 석사 및 박사학 위를 취득하였다. 한국지능정보시스템학회 이사 JITAM 편집위원 및 한국정보시스템학회, 한국경영정 보학회 종신회원으로 활동 중이다. 주요 관심분야는 시멘틱 데이터 관리, 데이터베이스 설계 및 데이터 마 이닝 등이다. 
$<$ Abstract $>$

\title{
Design and Application of PMO-Based Project Management Systems
}

\author{
Jeong, Cheon-Su $\cdot$ Kim, Seung-Ryeol $\cdot$ Kim, Nam-Gyu
}

Recently, Information System (IS) development projects such as the next generation IS project of the financial business domain have shown tendency to become large and complex. Accordingly, a large number of enterprises have introduced a Project Management Office (PMO) to successfully manage multiple complex large-scaled projects. Many researches and empirical studies have proved the positive results of PMO-based projects. For example, most PMO-based projects have been accomplished successfully without exceeding the planned deadline and budget. However, even in the case of PMO-based projects, participants are still supported by legacy Project Management Systems (PMS) developed without considering the PMO. It implies that recent large projects are hardly performed efficiently because of the large gap between the legacy PMS tools developed only for single small projects and the real process of PMO-based project management. Therefore, we attempt to design and develop a PMO-based PMS in which the role and responsibility of PMO are completely implemented. To demonstrate our systems practicality, we applied the devised system to the real project management cases of "K" bank in The Republic of Korea. According to the results of case analysis, all of the four projects supported by our PMO-based PMS have been completed without exceeding planned deadline and budget, and the quality of their final outcome is appraised to be superior.

Keywords: Project Management, Project Management Office, Project Management Systems, Information System Development

\footnotetext{
* 이 논문은 2011년 7월 26일 접수되어 1차수정(2011년 9월 1일)을 거쳐 2011년 11월 8일 게재 확정 되었습니다.
} 